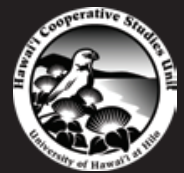

Prepared in collaboration with the Hawai'i Cooperative Studies, University of Hawai'i at Hilo

\title{
Vegetation Map of the Watersheds Between Kawela and Kamalō Gulches, Island of Moloka'i, Hawai'i
}

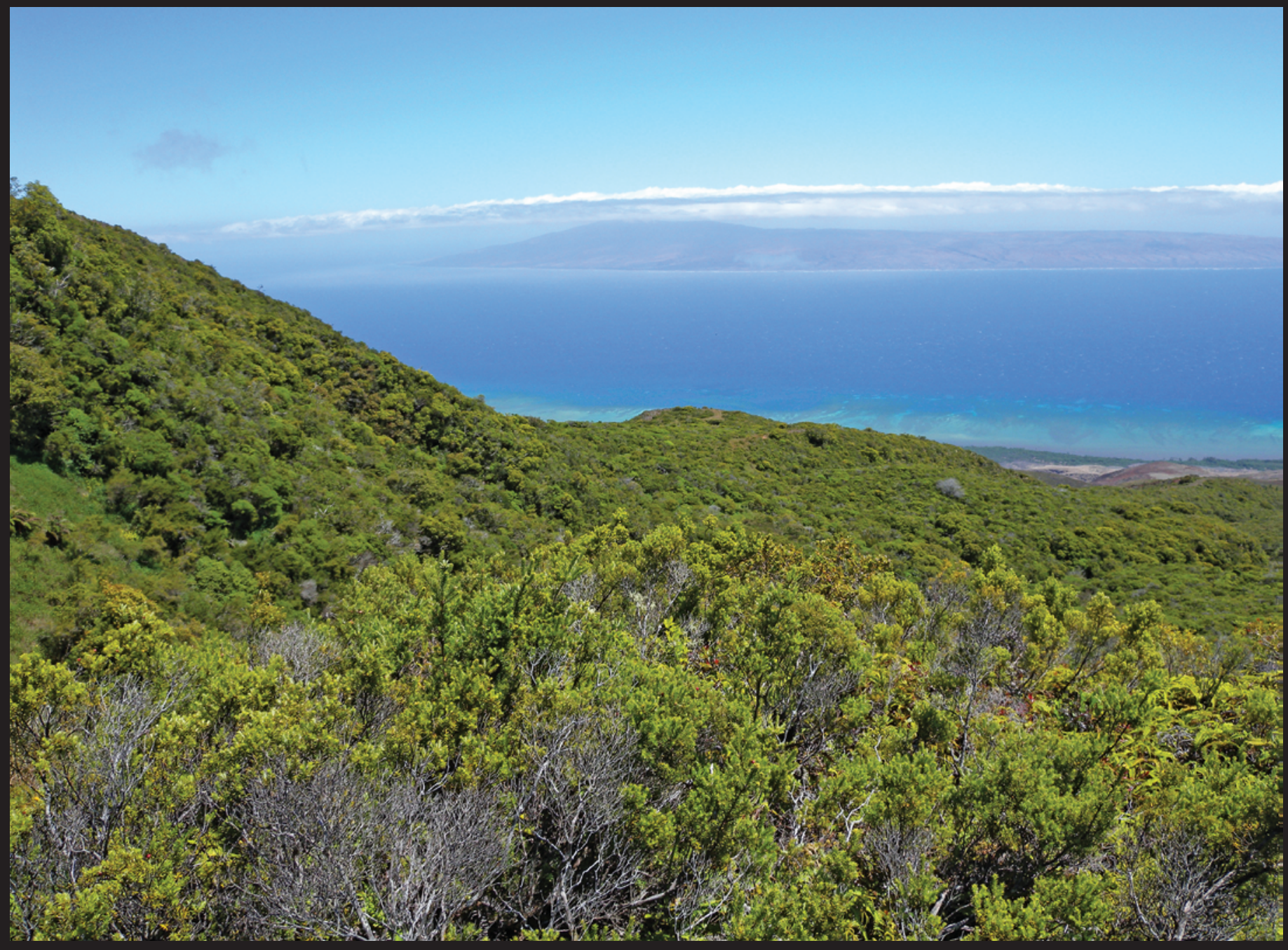

Scientific Investigations Report 2013-5093 


\section{Vegetation Map of the Watersheds Between Kawela and Kamalō Gulches, Island of Moloka'i, Hawai'i}

By James D. Jacobi and Stephen Ambagis

Prepared in collaboration with the Hawai'i Cooperative Studies, University of Hawai'i at Hilo

Scientific Investigations Report 2013-5093 


\section{U.S. Department of the Interior SALLY JEWELL, Secretary}

\section{U.S. Geological Survey \\ Suzette M. Kimball, Acting Director}

U.S. Geological Survey, Reston, Virginia: 2013

For more information on the USGS—-the Federal source for science about the Earth, its natural and living resources, natural hazards, and the environment, visit http://www.usgs.gov or call 1-888-ASK-USGS.

For an overview of USGS information products, including maps, imagery, and publications, visit http://www.usgs.gov/pubprod

To order this and other USGS information products, visit http://store.usgs.gov

Any use of trade, firm, or product names is for descriptive purposes only and does not imply endorsement by the U.S. Government.

Although this information product, for the most part, is in the public domain, it also may contain copyrighted materials as noted in the text. Permission to reproduce copyrighted items must be secured from the copyright owner. 


\section{Acknowledgments}

We would like to acknowledge many people who have helped throughout this project. Special thanks go to Ed Misaki and his staff (particularly Kathy Tachibana, Brian Neaole, and Sam Aruch) with The Nature Conservancy of Hawai 'i's, Moloka'i Office, as well as to all of the members of the East Moloka'i Watershed Partnership who are collaboratively managing this area to stabilize and restore the native ecosystems that have been subject to decades of impacts from grazing, logging, invasive species, and fire. We also deeply appreciate the support provided by the Kawela Plantation Homeowners Association, especially Juanita Colon, for allowing us to conduct our research throughout this landscape.

Henry Wolter of the U.S. Geological Survey (USGS, now retired) helped locate and acquire images used for mapping; Paul Berkowitz (Hawai'i Cooperative Studies Unit at the University of Hawai 'i at Hilo) helped with pulling together the seasonal images used for figure 4; and Jonathan Price (University of Hawai' $i$ at Hilo) helped us with interpreting the current and original vegetation of the project area. Linda Pratt and Keith Schulz provided very constructive comments when they reviewed the map and manuscript. Additionally, we would like to thank Bob and Elizabeth Granger, long-time residents of Kawela Plantations, who have always supported this project logistically and with their great hospitality and humor, particularly after a long and hot day in the field. Finally, this entire effort would not have been accomplished without support and camaraderie from the other members of the USGS Ridge-toReef Project: Pat Chavez, Mike Field, Maiana Hanshaw, Dave Helweg, Loyal Mehrhoff, Kevin Schmidt, Bill Steiner, John Stock, and Gordon Tribble-a truly indefatigable group of scientists and colleagues.

Funding for this project was provided by the Western Region and National Office of the USGS (Doug Buffington, Anne Kinsinger, Mike Schulters, and many others) under the Ecosystems and Invasive Species Programs, as well as from the USGS Pacific Island Ecosystems Research Center. Administrative support was provided by the Hawai 'i Cooperative Studies Unit and the USGS Pacific Island Ecosystems Research Center. 


\section{Contents}

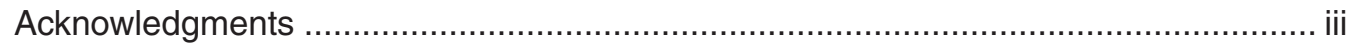

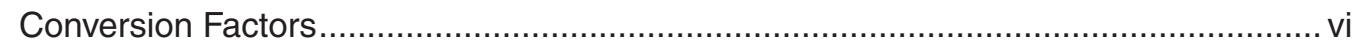

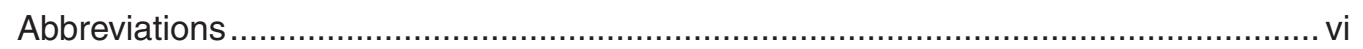

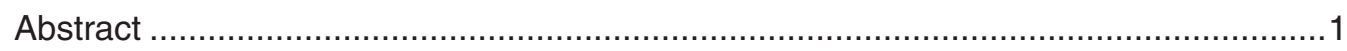

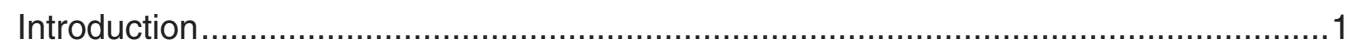

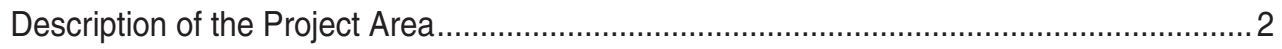

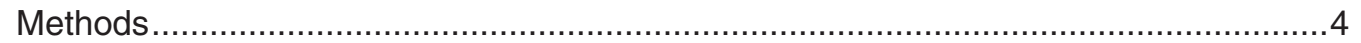

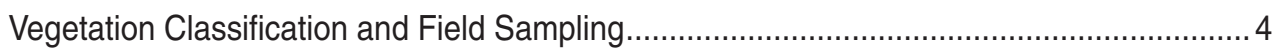

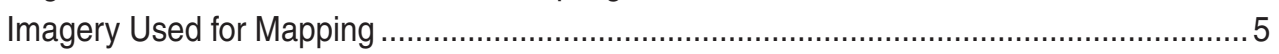

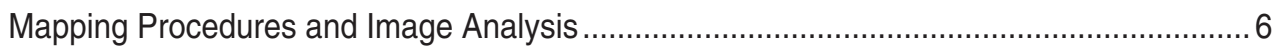

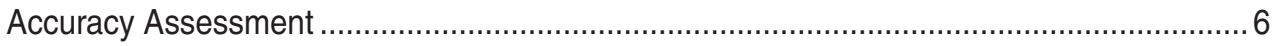

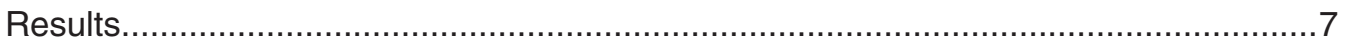

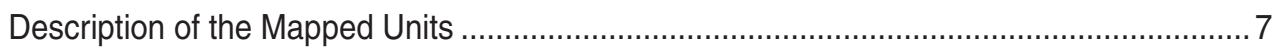

'Ōhi'a Montane Wet or Mesic Forest (Map Unit 1) ........................................9

Mixed Native Lowland Dry/Mesic Forest with Shrub/Grass Understory

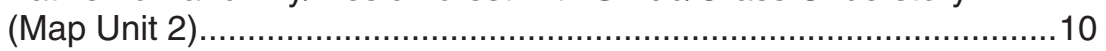

'Ōhi'a/Uluhe Montane Woodland (Map Unit 3) ..........................................10

Mixed Native Mesic Shrubland (Map Unit 4) ............................................11

'A'ali'i Dry Shrubland (Map Unit 5) .........................................................11

'Ilima and Mixed Grass Dry Shrubland (Map Unit 6) ..................................12

Kukui Forest (Map Unit 7) .................................................................13

Mixed Alien Forest with Alien Shrub/Grass Understory (Map Unit 8) ............13

Introduced Tree Plantation (Map Unit 9) ....................................................14

Kiawe Woodland with Alien Grass Understory (Map Unit 10) ......................14

Lantana Shrubland (Map Unit 11) ............................................................15

Koa Haole Shrubland (Map Unit 12) ......................................................15

Mixed Alien Grass with 'llima Shrubs (Map Unit 13) ....................................15

No Vegetation or Very Sparse Grasses / Shrubs (Map Unit 14)....................16

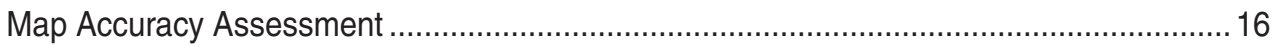

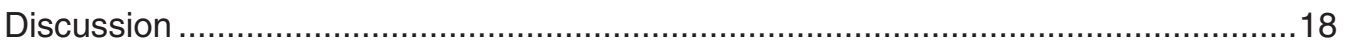

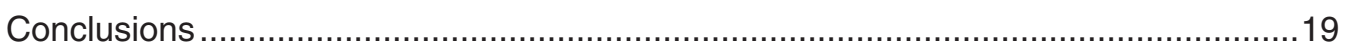

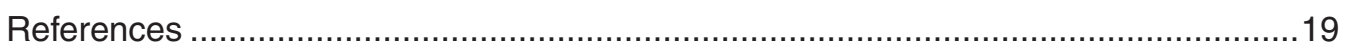

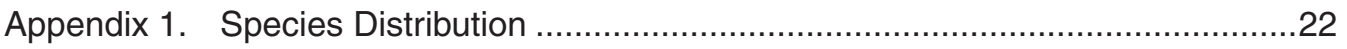

\section{Figures}

1. Map overview of the Kawela-Kamalō Ridge-to-Reef project area showing the vegetation map area, location of Nature Conservancy's Kamakou Preserve, contour intervals, and roads

2. Distribution of moisture zones and annual rainfall for the Kawela-Kamalo

Ridge-to-Reef project area

3. Distribution of general vegetation zones for the Kawela-Kamalō Ridge-to-Reef project area 
4. Map showing location of plots and photo points with vegetation classification units for the Kawela-Kamalō Ridge-to-Reef project area ..................................................

5. Two satellite images of the Kawela-Kamalō project area showing differences in the

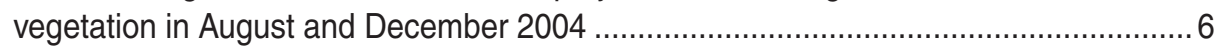

6. Map showing location of 100 random points used to assess accuracy of the vegetation map for the Kawela-Kamalō Ridge-to-Reef project area...............................................

7. Vegetation map produced for the Kawela-Kamalō Ridge-to-Reef project area......................9

8. Typical view in the 'Ōhi'a montane wet or mesic forest in the Kamakou Preserve

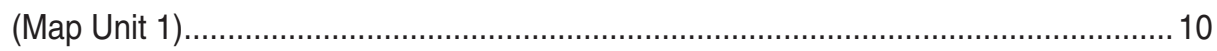

9. General view of the 'Ōhi'a montane wet or mesic forest in the upper portion of the

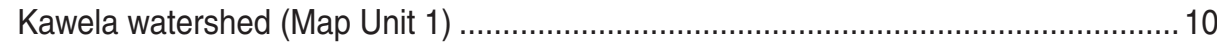

10. View of highly disturbed mixed mesic forest in the seasonal mesic moisture zone east of Kawela Gulch (Map Unit 2) ................................................................... 10

11. Remnant stand of wiliwili dry forest in a small gulch within the Kawela watershed

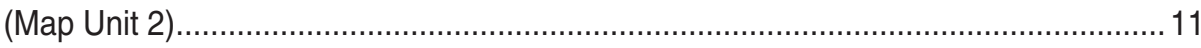

12. 'Ōhi'a/uluhe montane woodland in an opening in the mesic 'ōhi'a forest near Pu'u Kolekole (Map Unit 3).

13. Mixed native mesic shrubland dominated by 'ōhi'a, pūkiawe, and 'a'ali'i shrubs

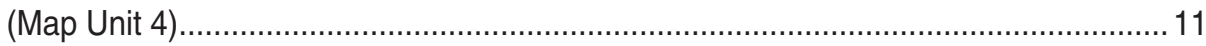

14. View of the mixed native mesic shrubland below Pu'u Kolekole (Map Unit 4).......................11

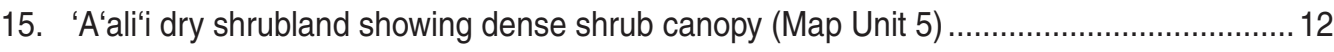

16. General view of 'a'ali'i dry shrubland in the Kawela watershed (Map Unit 5) .....................12

17. 'llima and mixed grass dry shrubland dominated by 'ilima at the edge of the east fork of Kawela Gulch (Map Unit 6) ............................................................................. 12

18. Very open vegetation, primarily 'ilima and Bidens pilosa shrubs with a few native

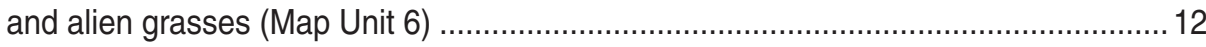

19. Stands of kukui trees in the bottom of Kawela Gulch, Moloka'i (Map Unit 7) ....................13

20. Tall-statured mixed alien forest in the lower section of Kawela Gulch (Map Unit 8) ............13

21. Low-statured mixed alien forest community in the lower part of Kamalō Gulch

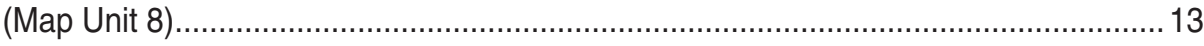

22. Aerial view of pine plantation at approximately $750 \mathrm{~m}$ elevation near Kawela Gulch (Map Unit 9)..... 14

23. Introduced tree plantation near Pu'u Kolekole, Moloka'i, dominated by Cupressaceae, Eucalyptus, and other broadleaf species (Map Unit 9)............................................. 14

24. Kiawe trees growing in grassland dominated by the alien buffelgrass (Map Unit 10) ......... 14

25. Kiawe woodland with alien grass understory community on the edge of Kawela Gulch

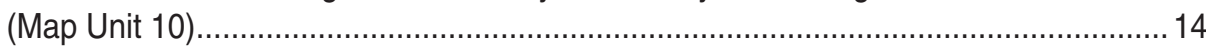

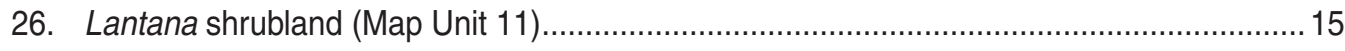

27. Koa haole shrubland in lower part of Kamalō Gulch (Map Unit 12) ................................... 15

28. Small stand of koa haole growing above alien grasses in the lower part of the Kawela

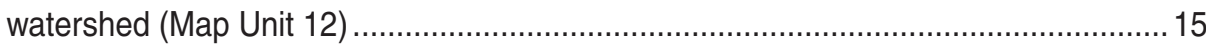

29. Mixed alien grassland dominated by buffelgrass (Map Unit 13) ........................................ 16

30. Close-up of buffelgrass and seedling of 'ilima (Map Unit 13) ........................................... 16

31. Not vegetated or very sparse grass/shrub community at the edge of the upper east fork of Kawela Gulch (Map Unit 14)..................................................................... 16

32. Steep slopes of the upper east fork of Kawela Gulch (Map Unit 14) ................................... 16 


\section{Tables}

1. Summary of vegetation plots and photo points used to calibrate the vegetation map units.... 4

2. Summary of the mapping units used to describe the plant communities, and the area covered by each unit on the map

3. Summary of the mapping units used to describe the plant communities, and the area covered by each unit on the map

4. Error matrix for the accuracy assessment conducted at 100 randomly located sample plots, depicting agreement or disagreement between the dominant class mapped in an assessment plot to the first-choice classification unit

5. Error matrix for the accuracy assessment conducted at 100 randomly located sample plots, depicting agreement or disagreement between the two most abundant classes mapped within an assessment plot to either the first- or second-choice classification unit

6. Error matrix for the accuracy assessment conducted at 100 randomly located sample plots

\section{Conversion Factors}

\begin{tabular}{lll}
\multicolumn{3}{c}{ SI to Inch/Pound } \\
\hline Multiply & By & To obtain \\
\hline centimeter (cm) & \multicolumn{1}{c}{ Length } \\
millimeter (mm) & 0.3937 & inch (in.) \\
meter (m) & 0.03937 & inch (in.) \\
& 3.281 & foot (ft) \\
\hline \multicolumn{2}{c}{ Area } & acre \\
\hline hectare (ha) & 2.471 &
\end{tabular}

\section{Abbreviations}

$\begin{array}{ll}\text { DEM } & \text { digital elevation model } \\ \text { DOQQ } & \text { digital orthophoto quarter quad map } \\ \text { EVT } & \text { existing vegetation type (LANDFIRE mapping program) } \\ \text { GAP } & \text { USGS Gap Analysis Program } \\ \text { GPS } & \text { Global Positioning System } \\ \text { LANDFIRE } & \text { USGS Landfire mapping program } \\ \text { NIR } & \text { near infrared spectral band } \\ \text { POL } & \text { Pictometry Online imagery service } \\ \text { RGB } & \text { red, green, blue spectral bands } \\ \text { USGS } & \text { U.S. Geological Survey } \\ \text { UTM } & \text { Universal Transverse Mercator }\end{array}$




\title{
Vegetation Map of the Watersheds Between Kawela and Kamalō Gulches, Island of Moloka'i, Hawai'i
}

\author{
By James D. Jacobi ${ }^{1}$ and Stephen Ambagis ${ }^{2,3}$
}

\section{Abstract}

In this document we describe the methods and results of a project to produce a large-scale map of the dominant plant communities for an area of 5,118.5 hectares encompassing the Kawela and Kamalō watersheds on the island of Moloka'i, Hawai' $i$, using digital image analysis of multi-spectral satellite imagery. Besides providing a base map of the area for land managers to use, this vegetation map serves as spatial background for the U.S. Geological Survey's (USGS) Moloka'i Ridge-to-Reef project, which is an interdisciplinary study of erosion and sediment transport within these watersheds. A total of 14 mapping units were identified for the KawelaKamalō project area. The most widespread units were the 'Ōhi 'a montane wet or mesic forest and No vegetation or very sparse grasses/shrubs communities, each present in more than 800 hectares, or 16 percent of the mapping area. Next largest were the Kiawe woodland with alien grass understory and 'A 'ali' $i$ dry shrubland units, each of which covered more than 500 hectares, or more than 12 percent of the area; followed by the Mixed native mesic shrubland, 'Ilima and mixed grass dry shrubland, Mixed alien grass with 'ilima shrubs, and the Mixed alien forest with alien shrub/grass understory communities, which ranged in size from approximately 391 to 491 hectares, or 7.6 to 9.6 percent of the project site. The other six mapped units covered less than 170 hectares of the landscape. Six of the map units were dominated by native vegetation, covering a total of 2,535.2 hectares combined, or approximately 50 percent of the project area. The remaining map units were dominated by nonnative species and represent vegetation types that have resulted from invasion and establishment of plant species that had been either purposely or accidently introduced into Hawai' $i$ since humans arrived in these islands more than 1,500 years ago. The preponderance of mapping units that are dominated by alien species of plants is a strong indication of how much anthropogenic disturbance has occurred in this area. The native-dominated 'Ōhi' a forest and uluhe fern communities are probably most similar to the vegetation that was originally found in the upper part of the project area this area. Portions of the mixed mesic native shrub community still persist in the lowland mesic zone, but below that area, the

${ }^{1}$ U.S. Geological Survey; jjacobi@usgs.gov

${ }^{2}$ Hawai 'i Cooperative Studies Unit, University of Hawai'i at Hilo, HI

${ }^{3}$ Current affiliation: Resource Mapping Hawai ‘i LLC, Kea'au, HI vegetation is either dominated by alien species, or artificially opened by animal grazing and erosion, even in the few units that are still dominated by native species. The map produced for the Kawela to Kamalō watersheds can be used as a baseline for assessing the distribution and abundance of the various plant communities found across this landscape at the time of the imagery (2004). It can also be used to help understand the dynamics of the vegetation and other attributes of this watershed-such as erosion and surface transport of sediment, relative to current and future habitat conditions.

\section{Introduction}

A vegetation map is one of the most important and basic tools used to assess the natural resources of an area as it serves as a background layer for interpreting the distribution and dynamics of the other biological elements present and provides the foundation for designing a field-sampling framework. The units displayed on a vegetation map reflect the results of either an objective or subjective classification process to identify consistent species associations or structural characteristics of the vegetation across the area of interest (Shimwell, 1971; Mueller-Dombois and Ellenberg, 1974), and may depict physiognomic, floristic, environmental, geographical, successional, or environmental features of the plant communities (Mueller-Dombois, 1984). In all cases, however, the classification units reflect some level of generalization of the continuum of spatial variation of the distribution and abundance of plants as they occur relative to the environment. While the boundaries between units are sometimes very distinguishable in the field (for example, following distinct edaphic or topographical features), more often they are drawn to represent the midpoint of the transition from one classification unit to another. Originally, maps were produced by sketching unit boundaries in the field, or by drawing boundaries around similar-appearing units on aerial photographs prior to compiling them onto a base map. More recently, multivariate analysis techniques have been applied to interpreting reflectance values for spatial data blocks (pixels) from digital images collected from aircraft or satellites (Brown de Colstoun and others, 2003; Xie and others, 2008; Wang, 2012). The combinations of reflectance values are used to build a probabilistic model (signature) that includes threshold levels of variation for each classification unit. 
Mapping plant communities in the Hawaiian Islands presents many challenges. Primary complicating factors are extreme topographic variation in many areas, availability of suitable imagery, and a large number of invasive plant species that have become established in an otherwise relatively simple set of native vegetation units. Additionally, the vegetation in dry habitats may appear to be very different during the wet season versus the dry season. Although the land area of the main Hawaiian Islands is relatively small, two of the islands (Hawai' $i$ and Maui) rise to over 3,000 meters (m) elevation, and many parts of these and the other islands are highly erodedresulting in steep terrain. This highly variable topography leads to problems interpreting the data because of shadows on the imagery, and to dramatic transitions in plant community composition and structure over short distances. Cloud cover and shadows also compromise the imagery, making it difficult to perform standard classification analysis using digital image analysis or photo-interpretation. Finally, while the native ecosystems generally have only a few canopy species or species associations that dominate the landscape, since human colonization of this archipelago thousands of species of plants and animals have been either intentionally or accidentally introduced and have become established in the native ecosystems (Smith, 1985; Staples and Cowie, 2001). Invasive species have led to major alteration of some of the original plant communities, particularly in lowland habitats, as well as the incorporation of alien plants into many of the remaining native vegetation units (Pratt and Gon, 1998; Warshauer, 1998; Pratt and Jacobi, 2009). As a result, a majority of the lowland communities are now (2012) dominated by introduced species at various stages of community succession, yielding an extremely high number of potential map units.

Many approaches have been used to map the vegetation of the Hawaiian Islands. These include extremely generalized (1:500,000 and smaller scale) maps depicting broad vegetation zones (for example, Robyns and Lamb, 1939; Ripperton and Hosaka, 1942; Krajina, 1963; Pratt and Gon, 1998); midscale maps $(1: 100,000-1: 500,000)$ displaying generalized plant communities, such as the Hawai 'i GAP land cover map (Gon and others, 2006) or the recent LANDFIRE EVT map by the USGS (U.S. Geological Survey, 2009); as well as very large scale maps $(1: 12,000-1: 100,000)$ with units that display very detailed plant communities with boundaries that could be identified relatively easily in the field (such as Mueller-Dombois, 1966; Jacobi, 1990; Shaw and Castillo, 1997; Cogan and others, 2011). This document describes the methods and results of a project to produce a large-scale map of the dominant plant communities for a 5,118.5-hectare (ha) area encompassing the Kawela and Kamalō watersheds on the Island of Moloka' $i$ using digital image analysis of multispectral satellite imagery. Besides providing a base map of the area for land managers to use, this vegetation map serves as spatial background for the USGS Moloka'i Ridge-to-Reef project, which is an interdisciplinary study of erosion and sediment transport within these watersheds (Stock and others, 2011). Research components of the Ridge-to-Reef project include an assessment of current vegetation and projected changes with ungulate control, collecting data on local climate conditions and surface water flow, modeling sediment mobilization and transport, and sediment impacts on the nearshore reef ecosystem.

\section{Description of the Project Area}

The Ridge-to-Reef project area is located on the southern side of east Moloka 'i. It extends from sea level to 1,365 m elevation (fig. 1), encompassing several ahupua'a (Hawaiian land divisions) including Kawela, Kamalō, Mākolelau, Kapuaoko'olau, and Keonekū'ino, as well as the major drainages of Kawela and Kamalō Gulches. The substrate of this area is predominantly highly weathered basaltic lava that was erupted between 1.75 and 1.31 million years ago and includes a few old cinder and spatter cones at upper elevations of the site (Sherrod and others, 2007). The extremely steep slope on this leeward side of the Island of Moloka' $i$ results in increasingly xeric conditions southward from the rim of Pelekunu Valley. Annual rainfall ranges from approximately 3,400 millimeters $(\mathrm{mm})$ at the top of the project area to approximately $305 \mathrm{~mm}$ at the coast (Giambelluca and others, 2011) (fig. 1). This leeward side of the island is driest during the summer months, with less than $5 \mathrm{~mm}$ of rainfall per month from June to September (Giambelluca and others, 2011). Price and others (2012) mapped this portion of the island as having seven moisture zones, generally arranged in horizontal bands with moisture decreasing downslope (fig. 2). These moisture zones can be linked to four broad vegetation zones within the project area (fig. 3).

The natural vegetation of the Hawaiian Islands has been heavily altered since human colonization starting more than 1,500 years ago (Kirch and Hunt, 1997; Kirch, 1998, 2007), and accelerating since Western contact in 1778. Lowland dry and mesic habitats, such as those found in the lower two-thirds of the Moloka'i project area, have been particularly impacted, with much of the native vegetation replaced by nonnative species as a result of damage from fire, logging, ungulate grazing and browsing, and competition from alien plants (Stone and Scott, 1985; Cuddihy and Stone, 1990; Pratt and Jacobi, 2009). The wet and montane mesic forest communities in the upper portion of the project area are protected as the Kamakou Preserve, and they are still relatively intact and dominated by native species because of intensive management of introduced plants and animals by The Nature Conservancy and the East Moloka'i Watershed partnership. However, most of the lowland mesic and dry habitats in this area are now dominated by alien shrubs, grasses, and trees, and they continue to be browsed and grazed by introduced ungulates, primarily feral goats (Capra hircus) and axis deer (Axis axis). Additionally, the dense alien grass cover in the drier habitats presents a continual fire danger, and much of this area has burned several times in recent history (E. Misaki, The Nature Conservancy of Hawai' $i$, oral commun., 2005). 


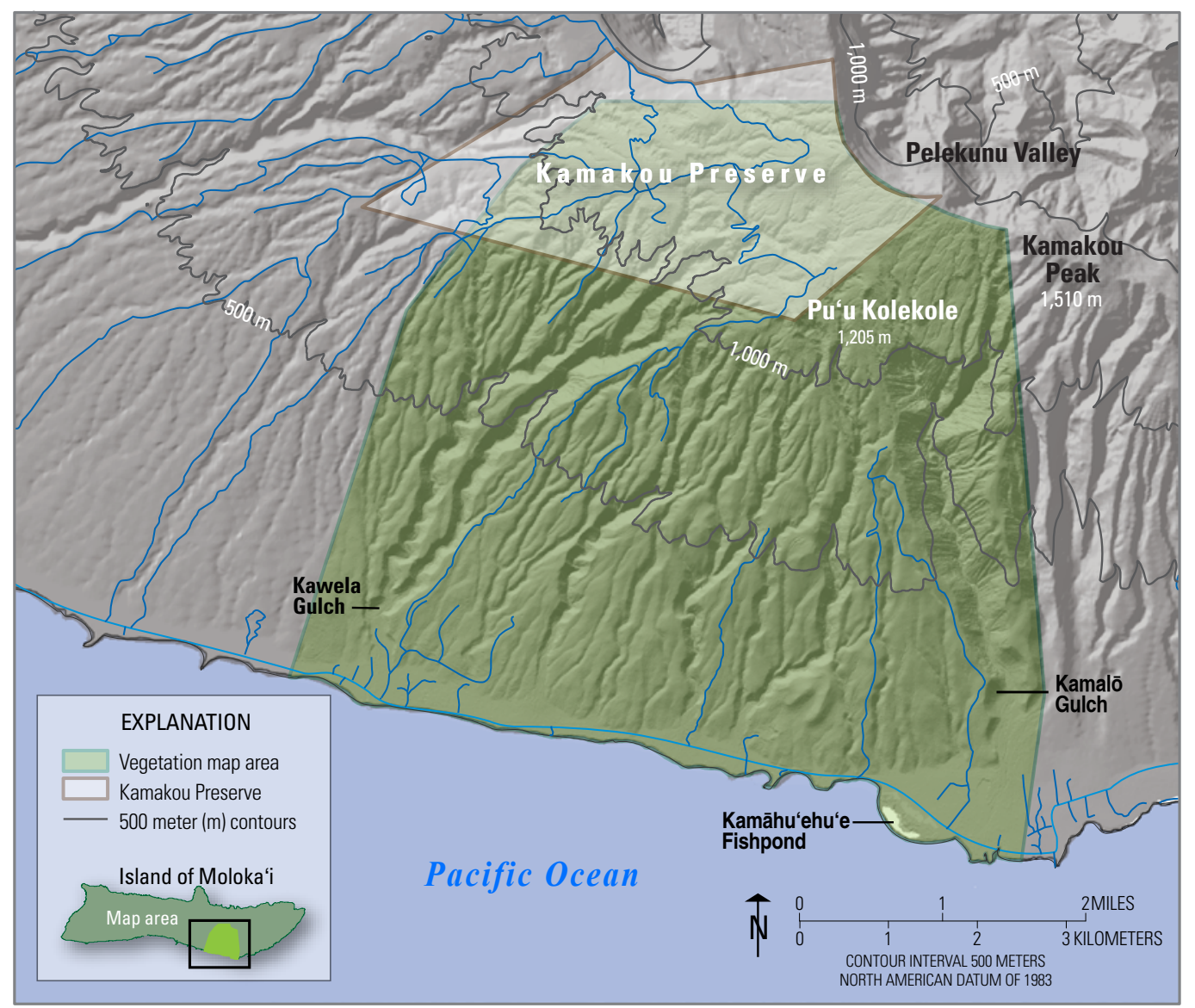

Figure 1. Map overview of the Kawela-Kamalō Ridge-to-Reef project area showing the vegetation map area, location of Nature Conservancy's Kamakou Preserve, contour intervals, and roads.

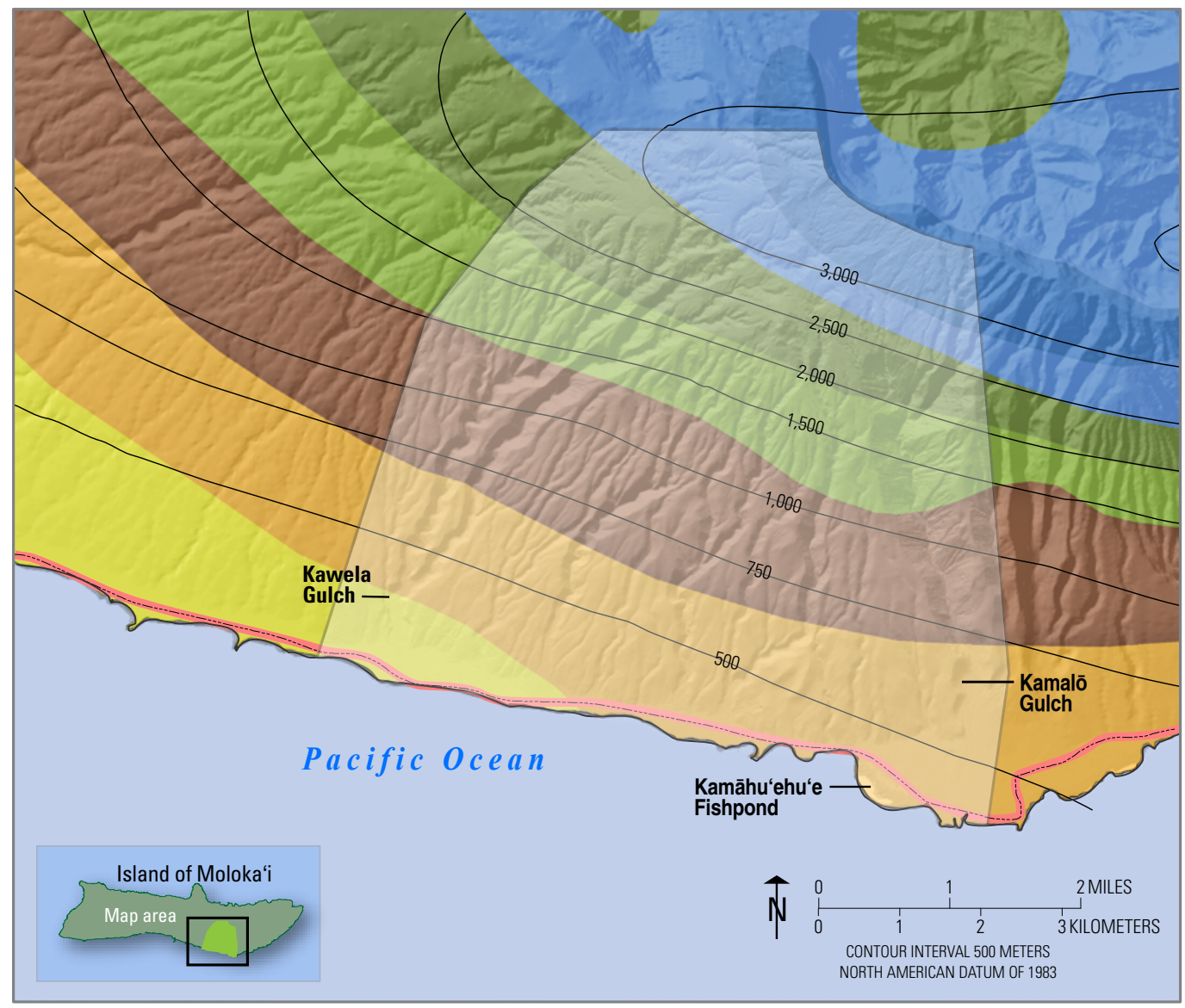

Figure 2. Distribution of moisture zones as mapped by Price and others (2012), and annual rainfall (isohyets) (Giambelluca and others, 2011) for the KawelaKamalō Ridge-to-Reef project area.

EXPLANATION

Moisture zones and rainfall

\begin{tabular}{l} 
Very wet \\
Moderately wet \\
Moist mesic \\
Seasonal mesic \\
Moderately dry \\
Very dry \\
Arid \\
$\square$ Vegetation map area \\
\hline- Major roads \\
Annual rainfall, \\
in millimeters (mm)
\end{tabular}




\section{Methods}

\section{Vegetation Classification and Field Sampling}

The plant communities mapped for the Moloka'i Ridgeto-Reef project area link directly to the alliance and association levels of the revised National Vegetation Classification (rUSNVC) which is based on the National Vegetation Classification Standard that was formally adopted by the Federal Geographic Data Committee (FGDC) in 2008. The rUSNVC classification expands upon on the original U.S. National Vegetation Classification
(Grossman and others, 1998), and the units also correspond with NatureServe's Terrestrial Ecological Systems Classification (NatureServe, 2010, 2011). This classification was also used to depict landcover in Hawai ' $i$ as part of the USGS LANDFIRE mapping project (U.S. Geological Survey, 2009).

Data on vegetation composition, cover, and structure were collected using a set of permanent plots, temporary plots, and photo points located throughout the project area (table 1; fig. 4). This information was used to correlate existing plant communities found within the project area with the vegetation classification units. Additionally, the ground plots were used to calibrate the image analysis for specific mapping units. Species names used in the description of the map units follow the taxonomy and nomenclature used by Wagner and others $(1999,2012)$.

Table 1. Summary of vegetation plots and photo points located throughout the project area used to calibrate the vegetation map units with the imagery used for mapping.

\begin{tabular}{lrl}
\hline \multicolumn{1}{c}{ Plot type } & Number & Description \\
\hline Erosion plots & 2 & $\begin{array}{l}\text { Two vegetation sampling plots, approximately 0.25 hectare each, one of which is fenced to exclude ungu- } \\
\text { late browsing and grazing }\end{array}$ \\
GPS photo points (April 2010) & 412 & $\begin{array}{l}\text { Geolocated photos taken of plant species and communities } \\
\text { Vegetation plots }\end{array}$ \\
Rapid assessment plots (August 2005) & 107 & 50-meter belt plots located subjectively to describe specific communities \\
Vegetation transect plots & 68 & 50-meter belt plots located systematically along a transect running downslope east of Kawela Gulch \\
\hline
\end{tabular}

Figure 3. Distribution of general vegetation zones for the Kawela-Kamalō Ridge-to-Reef project area, adapted from Price and others (2012).

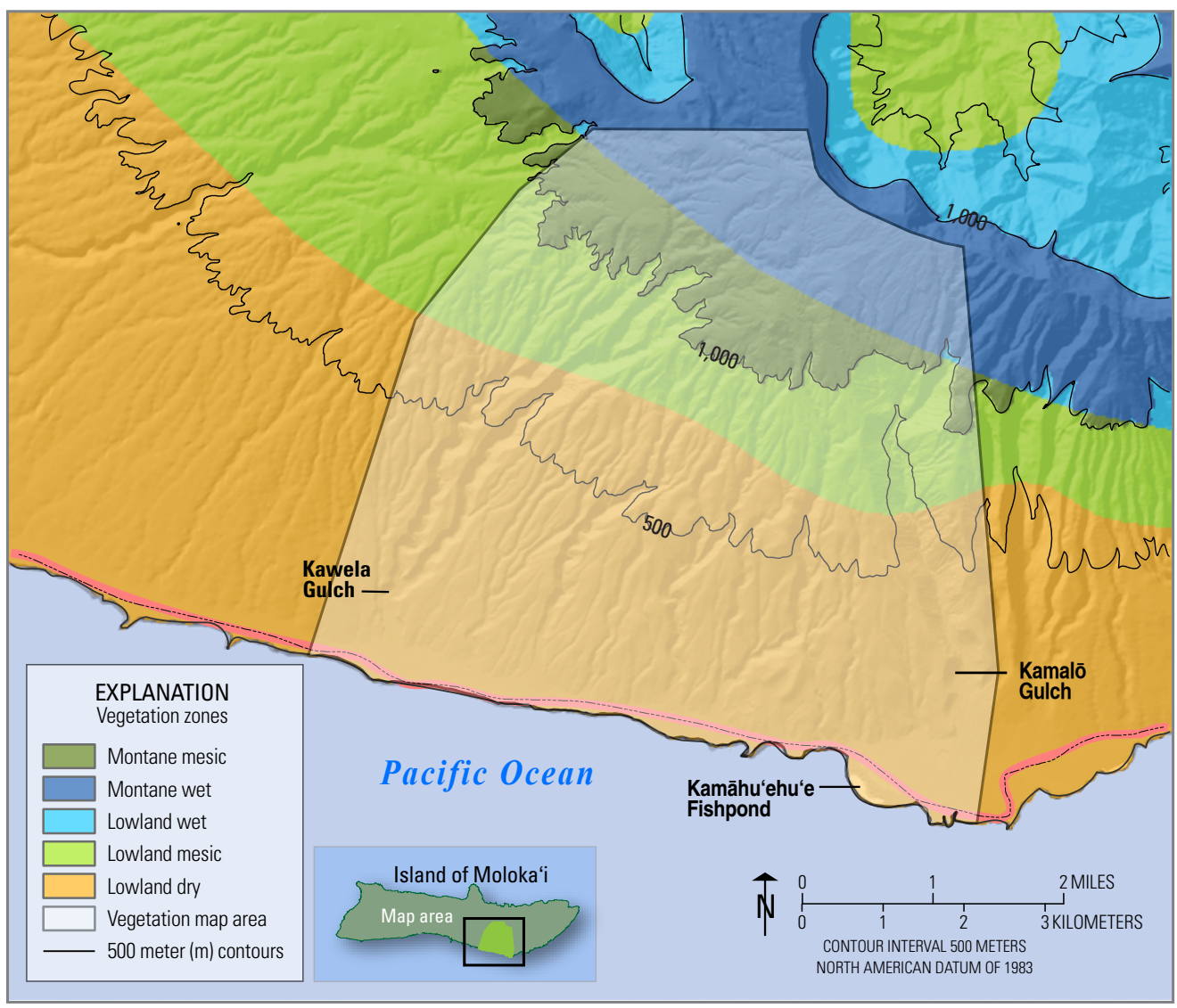




\section{Imagery Used for Mapping}

Several different types of images were used during this project. Primary mapping was conducted using a digital image collected by DigitalGlobe from its QuickBird satellite (Image number: 005507556010_01_P001_MUL and PAN), on August 19, 2004. This image has a pixel size of $2.4 \mathrm{~m}$ for the RGB (red, green, blue) and NIR (near infrared) spectral bands and $0.65 \mathrm{~m}$ for the panchromatic band. Additionally, both still and video images were taken of many areas throughout the project area from a helicopter or on the ground to further document the composition and structure of the mapped units.
The vegetation on this leeward side of Moloka 'i responds to the distinct wet and dry periods during the year. When the QuickBird images taken in August 2004 and December 2004 are compared (fig. 5), the December image shows much more green vegetation, particularly in the lower section of the project area. This is probably the result of vigorous new growth of alien grasses. We chose to map on the August 2004 image for two reasons: the sun angle in August was better, resulting in less shadow in the gulches; and we were able to avoid a potential problem with the vigorous grass growth from overwhelming the spectral signature of some of the mixed grass-shrub units.

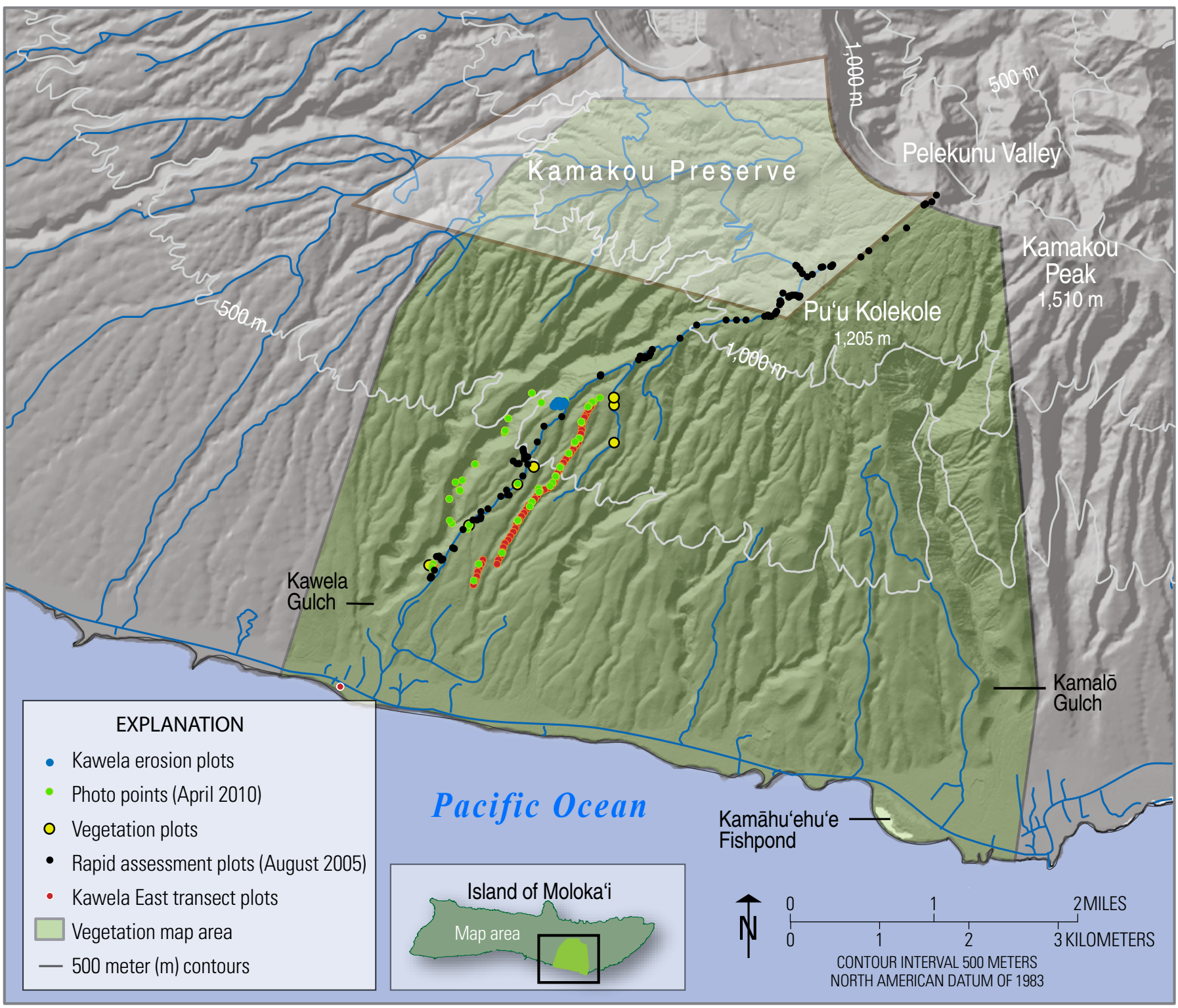

Figure 4. Map showing location of plots and photo points used to calibrate the image analysis with vegetation classification units for the Kawela-Kamalō Ridge-to-Reef project area. 


\section{Mapping Procedures and Image Analysis}

Preprocessing of the QuickBird image was necessary to ensure it was adequately orthorectified prior to classification. To do this we used a set of 50 control points collected from USGS Digital Orthophoto Quarter Quads (DOQQ) and the 10-m USGS digital elevation model (DEM), with cubic convolution resampling, to achieve 5- to 8-m horizontal accuracy. This initial step was performed using ERDAS Imagine 8.7 (Intergraph, now owned by Hexagon). Display and summary analysis of the mapped units was conducted using ArcMap 10.0 (Environmental Systems Research Institute, Redlands, California).

Primary image analysis and classification was conducted with an object-based image analysis strategy using the eCognition software program, originally developed by Difiniens AG, now owned by Trimble Navigation Ltd. eCognition utilizes a hierarchy of image objects to group and classify related pixels on digital images based on both spectral and shape characteristics of the data. Object-based analysis has been used successfully to differentiate detailed classification units by taking advantage of both spectral and size/shape characteristics of digital spatial data, particularly for image sets with high spatial resolution but a limited number of spectral bands, as is the case with QuickBird images (Blaschke, 2010). The first step in the process was to create a set of object primitives, or segments, based on a combination of spectral response and shape criteria. Once an acceptable initial segmentation was achieved the resulting pixel objects were linked to a preliminary set of the rUSNVC units, based on ground calibration points. An iterative process was then used to group the objects into temporary map units using a

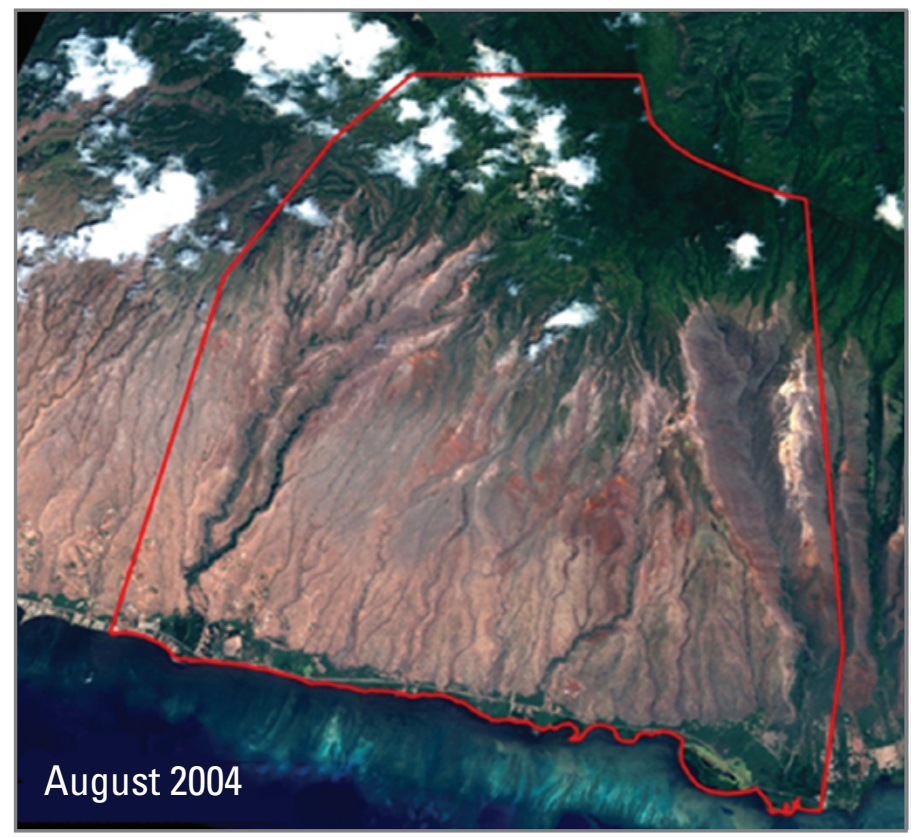

nearest neighbor classification and testing the classification by adding more ground calibration points. This process was continued until there was no significant change seen in the distribution and attributes of the classified units. In cases where single pixels or small groups of pixels that were obviously misclassified (for example, dry grassland within a closed wet forest community) were identified, they were homogenized with their adjacent neighbor pixels using the software program Grid Editor developed by ARIS B.V.

\section{Accuracy Assessment}

An accuracy assessment was conducted on the final vegetation map to describe the reliability of the mapping process when compared with actual vegetation on the ground following the procedures described by Congalton (1991) and Stehman and Czaplewski (1998). To do this we employed a random sampling design within a sampling frame that encompassed the entire mapping area. We randomly selected 100 assessment points using the Create Random Points tool in ArcMap 10.0 and produced a 25-m buffer around each of them using the Buffer tool to define the reference sample plots (fig. 6). We calculated the percentage of each plot that was covered by the different classification units on the map using the Tabulate Area tool in ArcMap10. To assess the reference or "true" values at each plot we recorded the classification unit value for each 25-m radius plot using the high-resolution Pictometry Online (POL) imagery and user interface developed by Pictometry International Corp. The POL images were taken during 2009 and 2010 and have a pixel size of approximately 15 centimeters $(\mathrm{cm})$. This allowed for a completely

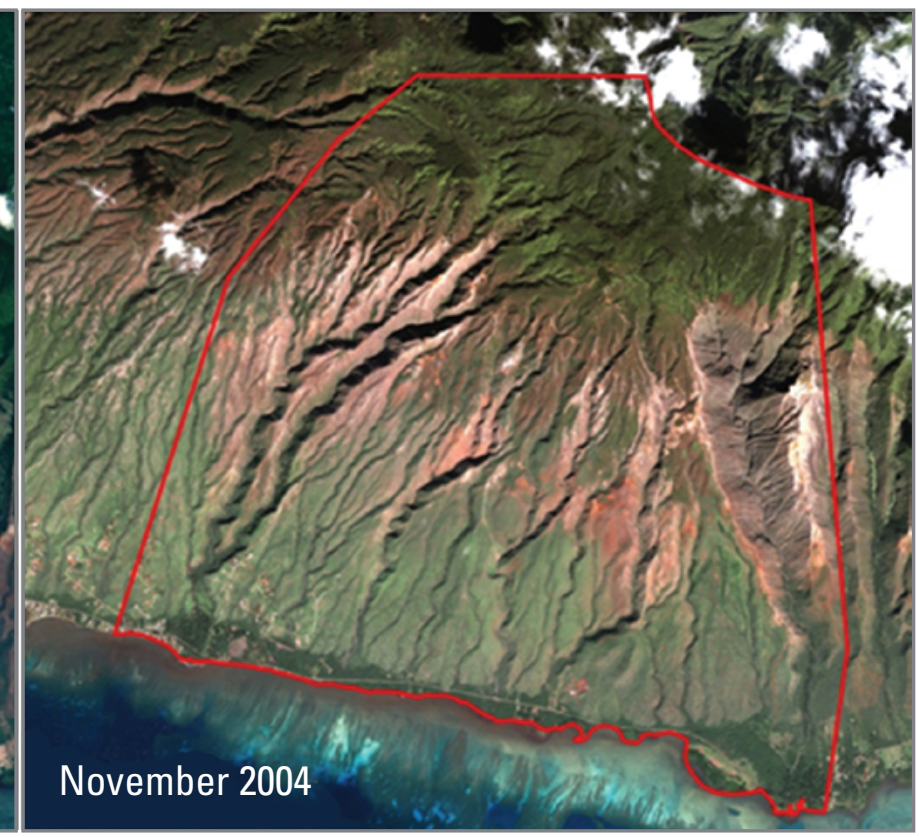

Figure 5. Two satellite images of the Kawela-Kamalō project area showing differences in the appearance of the vegetation on images taken by DigitalGlobe using its QuickBird satellite in August and December 2004. Vegetation map area outlined in red. 
independent process for testing the accuracy of the mapped units because the POL images were obtained separately from the QuickBird image used for primary analysis and mapping.

At each point on the POL imagery up to four map units were recorded, corresponding to the most abundant plant communities observed within $25 \mathrm{~m}$ of the coordinate point. Similarly, we analyzed the coded values for the pixels within a $25-\mathrm{m}$ radius plot on the vegetation map and summarized the mapped values all of the classification units that were mapped within the plot. Three error matrices were produced summarizing the omission and commission errors for three different configurations of the accuracy assessment data. This allowed for an objective assessment of the overall accuracy of the map (that is, the percentage of mapped pixels that were correctly classified), as well as the "producer's accuracy"-how well can a classification unit be mapped), and the "user's accuracy"- the probability that a pixel classified on a map is actually that unit on the ground (Congalton, 1991). The analyses included comparisons between (1) the dominant class mapped in an assessment plot to the first-choice classification unit from the POL image assessment; (2) the two most abundant classes mapped within an assessment plot to either the first- or second-choice classification unit from the POL image assessment; and (3) agreement or disagreement between any of the classes mapped within an assessment plot to any of the classification units identified within that plot during the POL image assessment.

\section{Results}

\section{Description of the Mapped Units}

A total of 14 mapping units were identified for the Kawela-Kamaō project area (table 2; fig. 7). Classification nomenclature includes both a simple unit name (for example, 'Ilima and mixed grass dry shrubland), as well as its formal rUSNVC name (for example, Waltheria indica/Sida fallax Shrubland) (NatureServe, 2010, 2011). The classification hierarchy for each unit relative to the rUSNVC, as well as a very simplified classification (Forest, Shrub/Open Woodland, Shrub, Grass, and Bare) that can be used to describe the area very generally are included in table 3 .

The most widespread units were the 'Ōhi' a montane wet or mesic forest and No vegetation or very sparse grasses/ shrubs communities, each present in more than 800 ha, or 16 percent of the mapping area. Next largest were the Kiawe woodland with alien grass understory and 'A 'ali' $i$ dry shrubland units, each of which covered more than 500 ha, or more than 12 percent of the area; followed by the Mixed native mesic shrubland, 'Ilima and mixed grass dry shrubland, Mixed alien grass with 'ilima shrubs, and the Mixed alien forest with

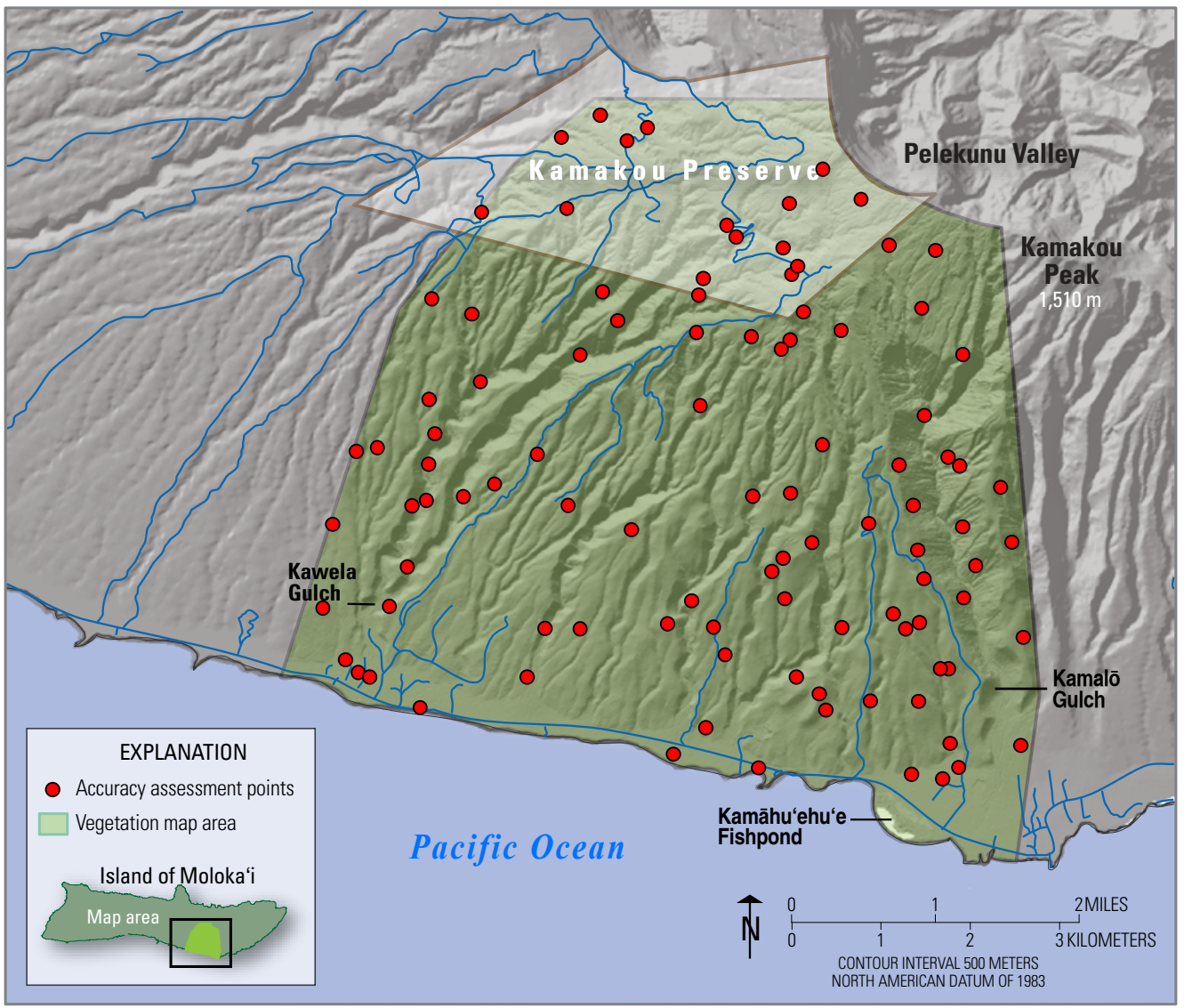

Figure 6. Map showing location of 100 random points used to assess accuracy of the vegetation map for the KawelaKamalō Ridge-to-Reef project area. 
Table 2. Summary of the mapping units used to describe the plant communities of the Kawela-Kamalo Ridge-to-Reef project area, and the area covered by each unit on the map.

\begin{tabular}{|c|c|c|c|c|c|}
\hline $\begin{array}{l}\text { Map } \\
\text { unit }\end{array}$ & Map unit name & Community type & $\begin{array}{c}\text { Area in } \\
\text { hectares }\end{array}$ & Area in acres & $\begin{array}{l}\text { Percent } \\
\text { of map }\end{array}$ \\
\hline 1 & 'Ōhi'a montane wet or mesic forest & Forest & 852.1 & $2,105.6$ & 16.6 \\
\hline 2 & Mixed native lowland dry/mesic forest with shrub/grass understory & Open forest & 16.5 & 40.8 & 0.3 \\
\hline 3 & 'Ōhi'a/uluhe montane woodland & Shrub/open woodland & 26.5 & 65.5 & 0.5 \\
\hline 4 & Mixed native mesic shrubland & Shrub & 495.0 & $1,223.2$ & 9.7 \\
\hline 5 & 'A'ali'i dry shrubland & Shrub & 654.2 & $1,616.6$ & 12.8 \\
\hline 8 & Mixed alien forest with alien shrub/grass understory & Forest & 390.7 & 965.4 & 7.6 \\
\hline 9 & Introduced tree plantation & Forest & 43.9 & 108.5 & 0.9 \\
\hline 10 & Kiawe woodland with alien grass understory & Grass/shrub/woodland & 737.5 & $1,822.4$ & 14.4 \\
\hline 11 & Lantana shrubland & Shrub & 10.7 & 26.4 & 0.2 \\
\hline 12 & Koa haole shrubland & Shrub & 168.6 & 416.6 & 3.3 \\
\hline
\end{tabular}

Table 3. Summary of the mapping units used to describe the plant communities of the Kawela-Kamalo Ridge-to-Reef project area and the area covered by each unit on the map.

\begin{tabular}{|c|c|c|c|}
\hline $\begin{array}{l}\text { Map } \\
\text { unit }\end{array}$ & Map unit name & rUSNVC associations & rUSNVC groups \\
\hline 1 & 'Ōhi'a montane wet or mesic forest & $\begin{array}{l}\text { Metrosideros polymorpha / cheirodendron spp. Montane wet forest } \\
\text { Metrosideros polymorpha / cibotium spp. Montane wet forest } \\
\text { Metrosideros polymorpha / mixed shrub montane wet forest } \\
\text { Metrosideros polymorpha montane mesic forest }\end{array}$ & $\begin{array}{l}\text { Hawaiian montane rainforest and cloud forest group } \\
\text { Hawaiian montane-subalpine seasonal rainforest group }\end{array}$ \\
\hline 2 & $\begin{array}{l}\text { Mixed native lowland dry/mesic forest with } \\
\text { shrub/grass understory }\end{array}$ & $\begin{array}{l}\text { Diospyros sandwicensis lowland mesic forest } \\
\text { Pleomele auwahiensis lowland mesic woodland } \\
\text { Diospyros sandwicensis lowland dry forest } \\
\text { Erythrina sandwicensis lowland dry forest }\end{array}$ & $\begin{array}{l}\text { Hawaiian lowland - coastal seasonal rainforest group } \\
\text { Hawaiian lowland dry forest and woodland group }\end{array}$ \\
\hline 3 & 'Ōhi'a/uluhe montane woodland & Metrosideros polymorpha / dicranopteris spp. montane wet woodland & Hawaiian montane rainforest and cloud forest group \\
\hline 4 & Mixed native mesic shrubland & $\begin{array}{l}\text { Dodonaea viscosa }-{ }^{1} \text { styphelia tameiameiae lowland mesic shrubland } \\
\text { Sadleria cyatheoides - metrosideros polymorpha dwarf-shrubland }\end{array}$ & $\begin{array}{l}\text { Hawaiian lowland mesic-wet shrubland and grassland } \\
\text { group } \\
\text { Hawaiian montane-subalpine mesic-wet shrubland and } \\
\text { grassland group }\end{array}$ \\
\hline 8 & $\begin{array}{l}\text { Mixed alien forest with alien shrub/grass } \\
\text { understory }\end{array}$ & $\begin{array}{l}\text { Grevillea robusta lowland mesic forest [provisional] } \\
\text { Samanea saman/prosopis pallida / leucaena leucocephala lowland dry } \\
\text { forest ['preliminary] }\end{array}$ & $\begin{array}{l}\text { Hawaiian ruderal dry forest group } \\
\text { y }\end{array}$ \\
\hline 9 & Introduced tree plantation & $\begin{array}{l}\text { Eucalyptus spp./Pinus spp./Cryptomeria japonica tree plantation } \\
\text { [preliminary] }\end{array}$ & (No group) \\
\hline 10 & Kiawe woodland with alien grass understory & Prosopis pallida coastal dry semi-natural woodland & Hawaiian ruderal dry forest group \\
\hline 11 & Lantana shrubland & Lantana camara shrubland [provisional] & $\begin{array}{l}\text { Hawaiian ruderal lowland shrubland, grassland and } \\
\text { savanna group }\end{array}$ \\
\hline 12 & Koa haole shrubland & Leucaena leucocephala lowland dry semi-natural shrubland & $\begin{array}{l}\text { Hawaiian ruderal lowland shrubland, grassland and } \\
\text { savanna group }\end{array}$ \\
\hline 13 & Mixed alien grass with 'Ilima shrubs & Cenchrus ciliaris lowland dry grassland [preliminary] & $\begin{array}{l}\text { Hawaiian ruderal lowland shrubland, grassland and } \\
\text { savanna group }\end{array}$ \\
\hline
\end{tabular}

\footnotetext{
${ }^{1}$ Currently accepted name is Leptecophylla tameiameiae (Wagner et al. 2012).

2 "Provisional" = This unit has not been formally recognized within the rUSNVC.

3 "Preliminary" = This is a new unit that will be proposed for inclusion within the rUSNVC.
} 


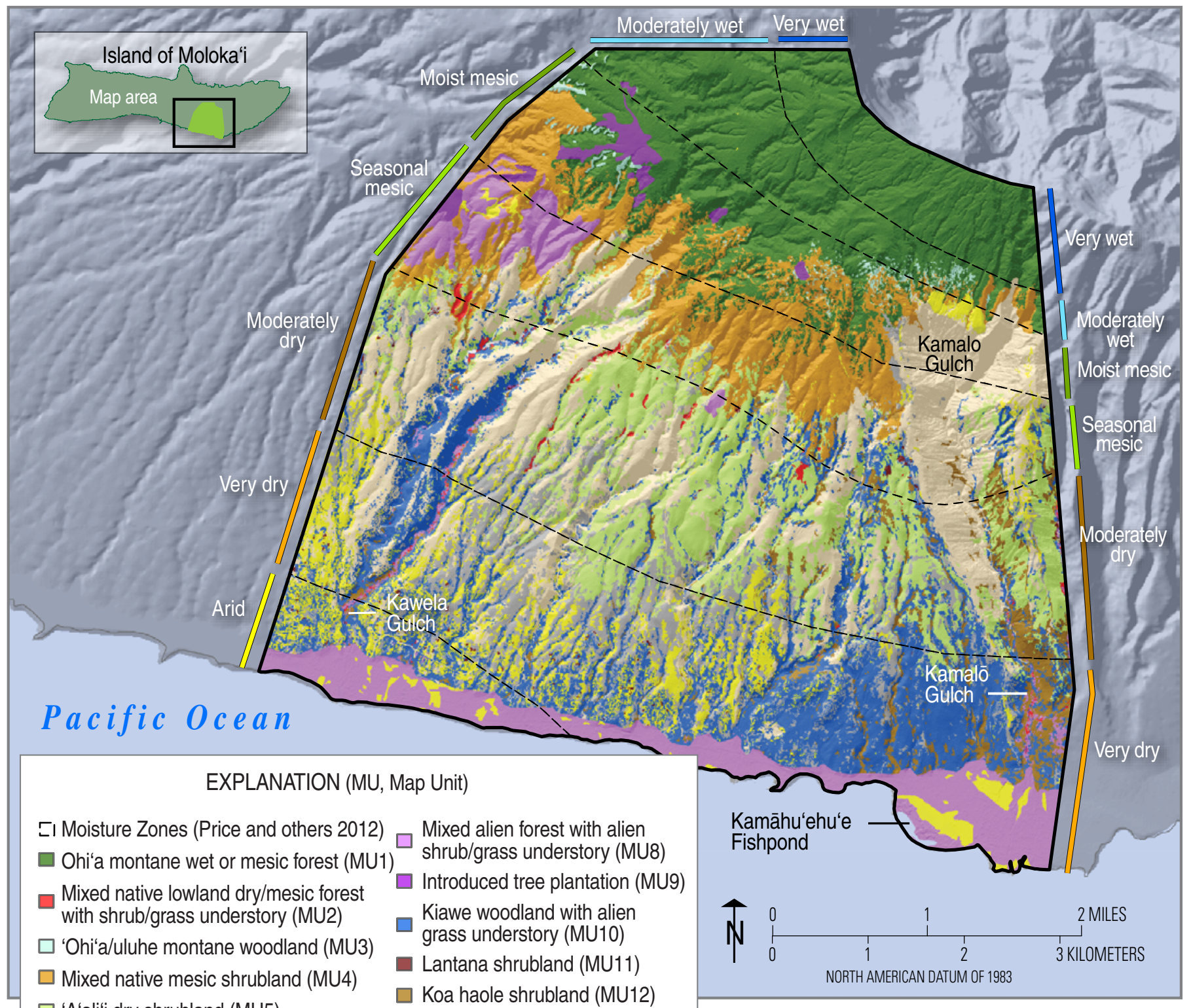

$\square$ 'A'alii'i dry shrubland (MU5)

$\square$ 'llima and mixed grass dry shrubland (MU6)

$\square$ Kukui forest (MU7) Mixed alien with 'ilima shrubs (MU13)

No vegetation or very sparse grasses/shrubs (MU14)

Figure 7. Vegetation map produced for the KawelaKamalō Ridge-to-Reef project area.

alien shrub/grass understory communities, which ranged in size from approximately 391 to 491 ha, or 7.6 to 9.6 percent of the project site. The other six mapped units were found on less than 170 ha of the landscape.

Six of the map units were dominated by native vegetation, covering a total of 2,535.2 ha combined, or approximately 50 percent of the project area. The remaining map units were dominated by nonnative species and represent vegetation types that have resulted from invasion and establishment of plant species either purposely or accidently introduced into Hawai'i since human contact.

\section{‘Ōhi'a Montane Wet or Mesic Forest (Map Unit 1)}

Closed canopy forest dominates the upper elevation part of the mapping area, ranging from approximately 1,000 m elevation up to the southern rim of Pelekunu Valley near Kamakou Peak at $1,510 \mathrm{~m}$ (figs. 8 and 9). This unit includes 852.1 ha of both mesic and wet habitat types. The mesic forest is generally found in areas with 2,000 to $2,700 \mathrm{~mm}$ annual rainfall; the wet component is at the higher elevations where annual rainfall exceeds 2,700 $\mathrm{mm}$. In all forested areas the tree canopy is dominated by 'ōhi 'a (Metrosideros polymorpha) with scattered other subcanopy trees, 


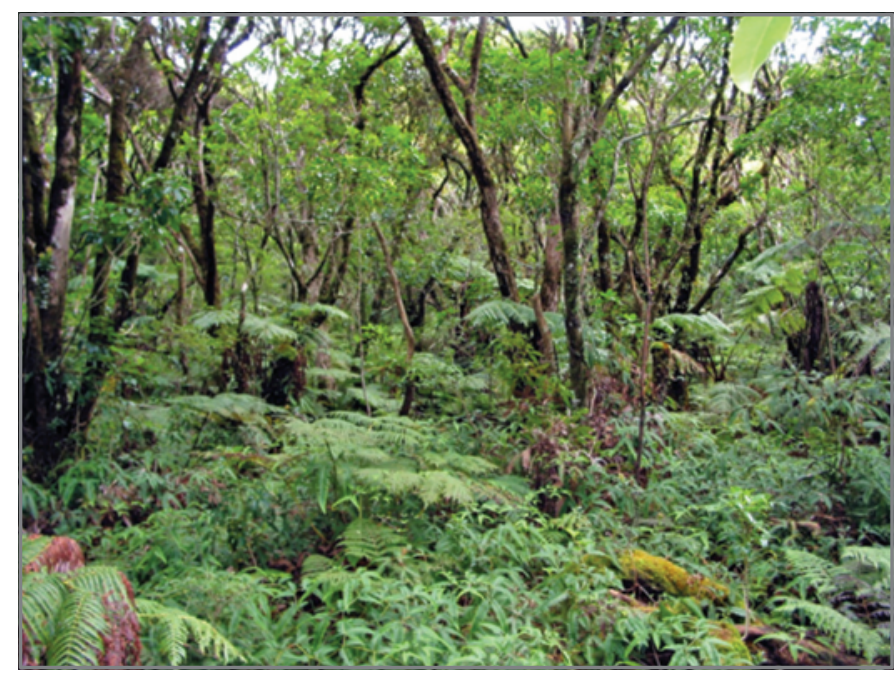

Figure 8. Typical view in the 'Ōhi'a montane wet or mesic forest in the Kamakou Preserve, Moloka'i. (Map Unit 1)

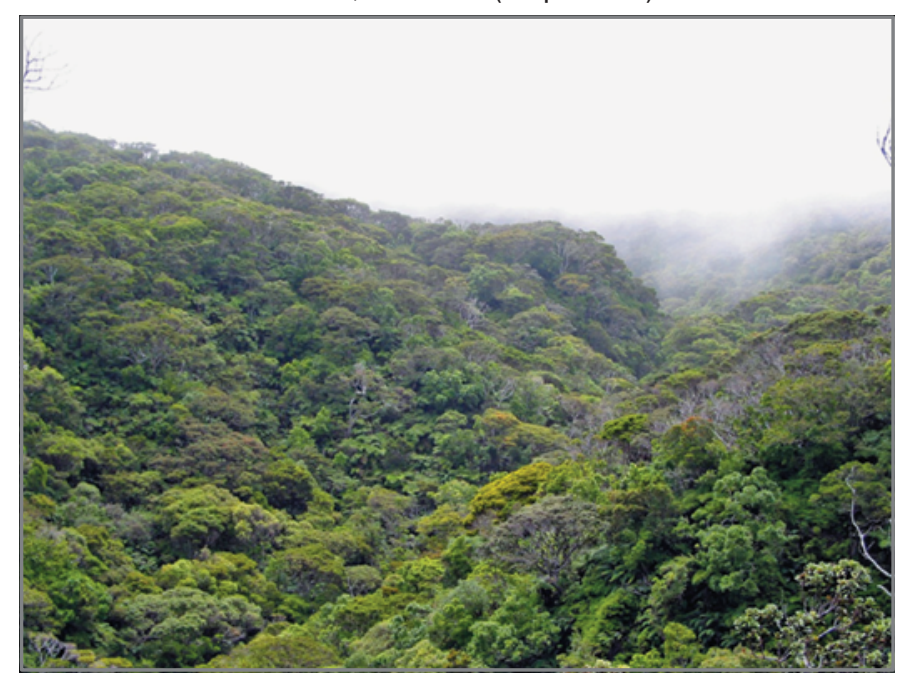

Figure 9. General view of the 'Ōhi'a montane wet or mesic forest in the upper portion of the Kawela watershed. (Map Unit 1)

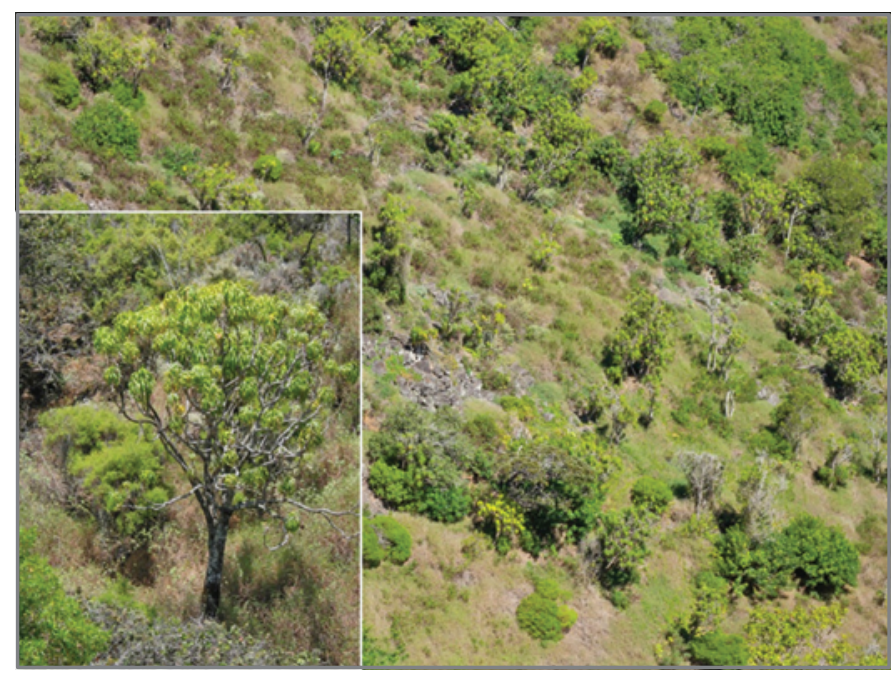

Figure 10. View of highly disturbed mixed mesic forest in the seasonal mesic moisture zone east of Kawela Gulch, Moloka'i. Dominant trees include halapepe (inset), lama, naio, and 'iliahi. (Map Unit 2) including 'ōlapa (Cheirodendron trigynum) and kōlea (Myrsine spp.). In the lower mesic sections of this mapped unit the understory is dominated by a mix of native shrubs and ferns, as well as some uluhe (Dicranopteris linearis) under canopy openings. In the upper wet sections of this forest, the understory is again dominated by native shrub and fern species, but also includes more hāpu'u tree ferns (Cibotium spp.). Most of this wet and mesic habitat, including the mixed mesic native shrub community described below, has been fenced to protect it from the impacts of feral pigs (Sus scrofa), goats, and axis deer within The Nature Conservancy's Kamakou Preserve and adjacent lands managed by the East Moloka'i Watershed Partnership.

\section{Mixed Native Lowland Dry/Mesic Forest with Shrub/Grass Understory (Map Unit 2)}

Lowland communities in the main Hawaiian Islands have been severely altered by land-use changes for agriculture and urban development, browsing by feral ungulates, as well as invasion by nonnative plant species (Cuddihy and Stone, 1990; Warshauer,1998; Pratt and Jacobi, 2009). Lowland mesic and dry forests in particular have been greatly reduced from their original extent and those that remain have a reduced number of species, particularly in the understory. Within the KawelaKamalō project area, just a few remnants of mixed native dry/ mesic forest remain, mostly along the edges of the larger gulches where they are less accessible to browsing by feral goats and introduced axis deer, or in the bottoms of the many drainages found across the watershed (fig. 10). In this study, only 16.5 ha of mixed native dry/mesic forest were mapped within the project area. This highly degraded community likely contained a great diversity of endemic tree, shrub, and fern species, but it is now reduced to those native woody species that have been able to survive, including halapepe (Pleomele auwahiensis), lama (Diospyros sandwicensis), naio (Myoporum sandwicense), and 'iliahi (Santalum ellipticum). The lower dry forest is dominated primarily by the native trees wiliwili (Erythrina sandwicensis), lama, and naio (fig. 11). We speculate that this community type was originally much more widespread across the KawelaKamalō watersheds prior to Western contact more than 200 years ago, extending in a band across the lower landscapes below approximately $700 \mathrm{~m}$ elevation, where annual rainfall is less than $1,200 \mathrm{~mm}$.

\section{'Ōhi'a/Uluhe Montane Woodland (Map Unit 3)}

This plant community is relatively simple in composition, being dominated by a dense mat of uluhe ferns in the montane wet and mesic forest zones where the tree canopy is open (fig. 12). The uluhe patches are generally not very large and are mixed into the matrix of montane 'ohi' a forest in small openings in the forest canopy or on steeper slopes that have fewer tall trees. A total of 26.5 ha of this unit were mapped, all above 1,000 $\mathrm{m}$ elevation in the zone that receives more than $2,000 \mathrm{~mm}$ of annual rainfall. 


\section{Mixed Native Mesic Shrubland (Map Unit 4)}

The mixed mesic native shrub community is relatively rich in composition, including some elements of the adjacent montane mesic 'Ōhi'a forest above it, as well as species from the lower elevation dry communities (figs. 13, 14). This community forms a distinct band between approximately 700 and 1,100 m elevation, primarily within the moist mesic and seasonal mesic moisture zones mapped by Price and others (2012), receiving between 1,300 and 2,700 $\mathrm{mm}$ of rainfall per year. More than 495.0 ha of this community were mapped, occupying 9.7 percent of the project area. The vegetation is generally less than $2 \mathrm{~m}$ in height and is dominated by several native shrub species including a smaller form of 'ōhi'a, 'a'ali'i (Dodonaea viscosa), pūkiawe (Leptecophylla tameiameiae), 'ōhelo (Vaccinium spp.), and pilo (Coprosma spp.). Additionally, it contains a mix of ferns such as 'ama'u (Sadleria spp.), uluhe, and Dryopteris wallichiana. The

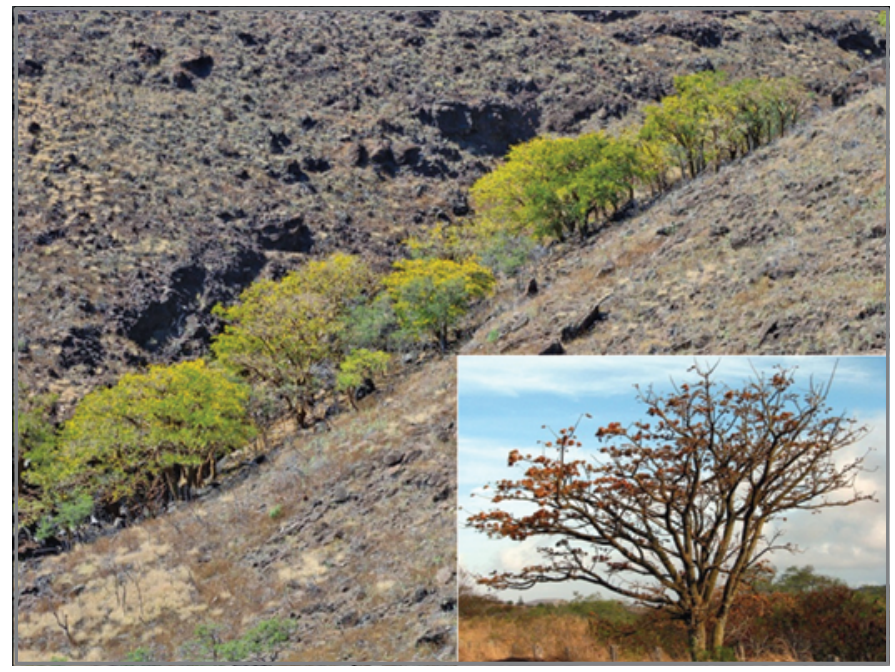

Figure 11. Remnant stand of wiliwili (seen flowering in inset photo) dry forest in a small gulch within the Kawela watershed, Moloka'i. (Map Unit 2)

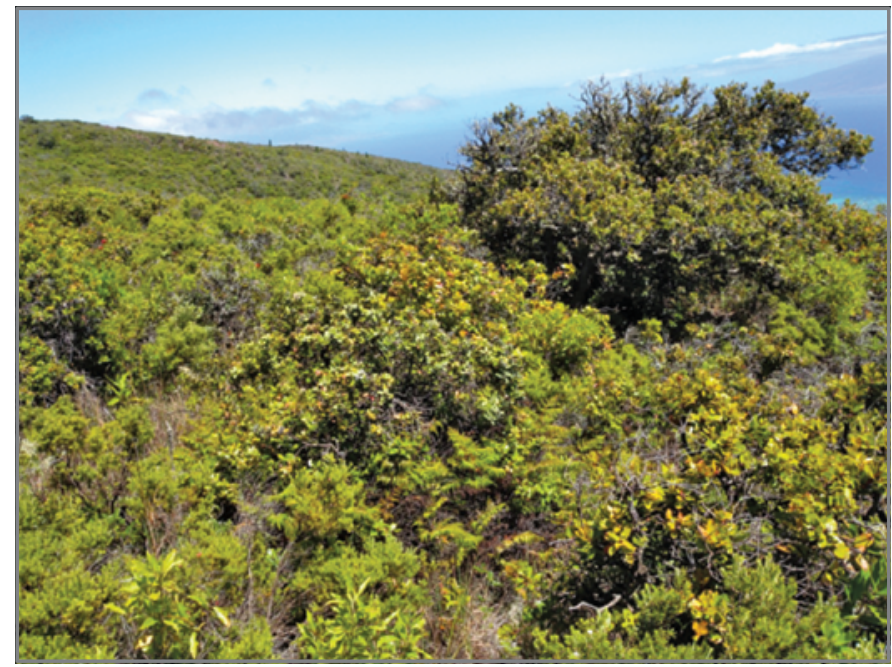

Figure 13. Mixed native mesic shrubland dominated by 'ōhi'a, pūkiawe, and 'a'alii'i shrubs. (Map Unit 4). current lower extent of this community has been modified by decades of grazing by feral (goats and cattle) and wild (axis deer) ungulates in this area, as well as from the many fires that have burned this habitat.

\section{‘A'ali'i Dry Shrubland (Map Unit 5)}

More than 654.2 ha of the 'A 'ali'i dry shrubland community were mapped, generally between 200 and 800 $\mathrm{m}$ elevation in the relatively dry middle section of the project area, which receives less than $1,500 \mathrm{~mm}$ of annual rainfall (figs. 15, 16). Less of this community was found in the western part of the project area than in the central and eastern parts. 'A 'ali'i shrubland occurs both on the sides of gullies and in the flatlands between gulches where it forms dense thickets that can be difficult to walk through. The vegetation is dominated by the indigenous shrub ' $a$ 'ali' $i$ with few other

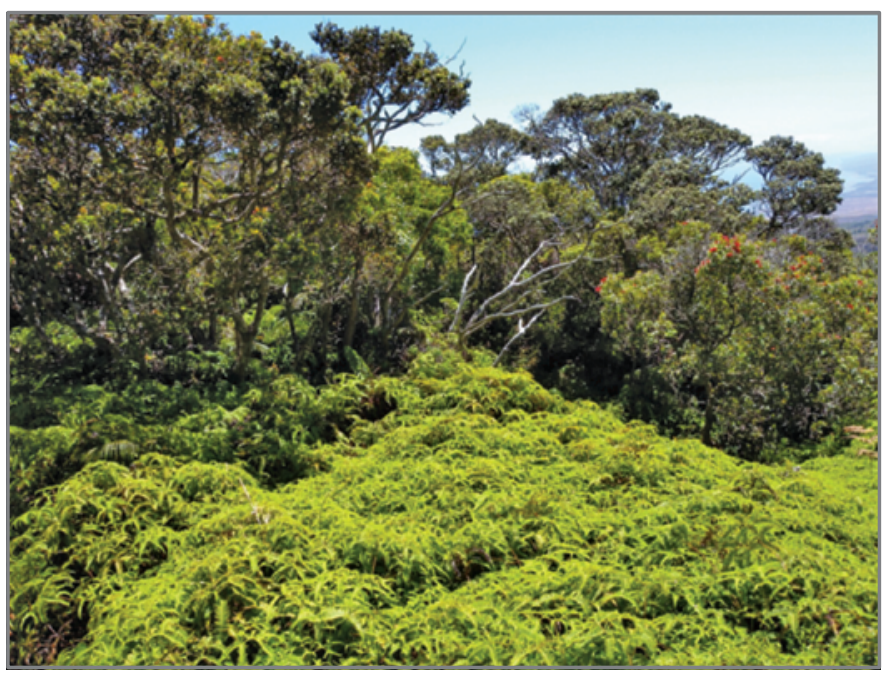

Figure 12. 'Ōhi'a/uluhe montane woodland in an opening in the mesic 'ōhi'a forest near Pu'u Kolekole, Moloka'i. (Map Unit 3)

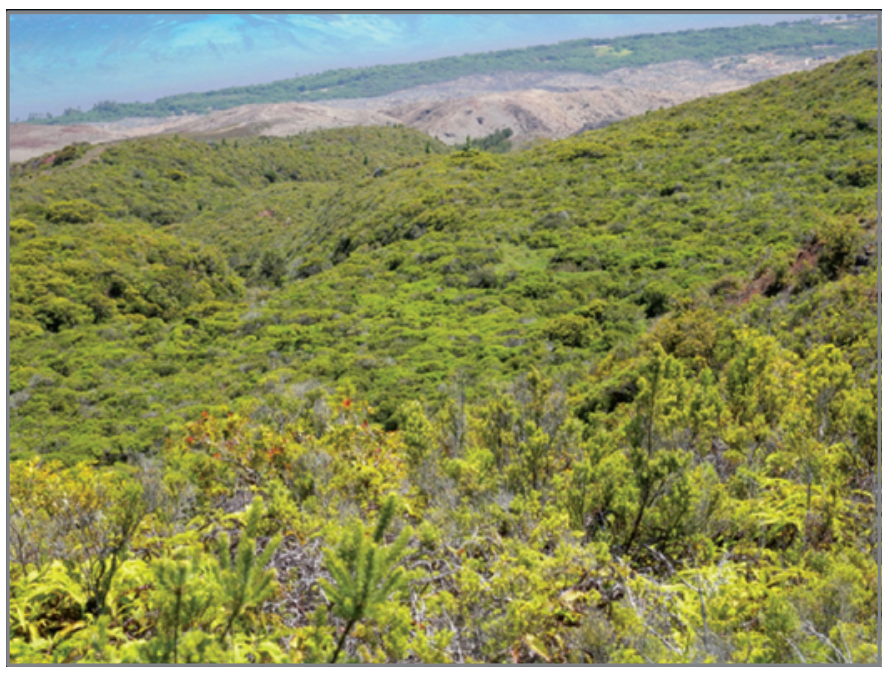

Figure 14. View of the mixed native mesic shrubland below Pu'u Kolekole, Moloka'i. (Map Unit 4) 


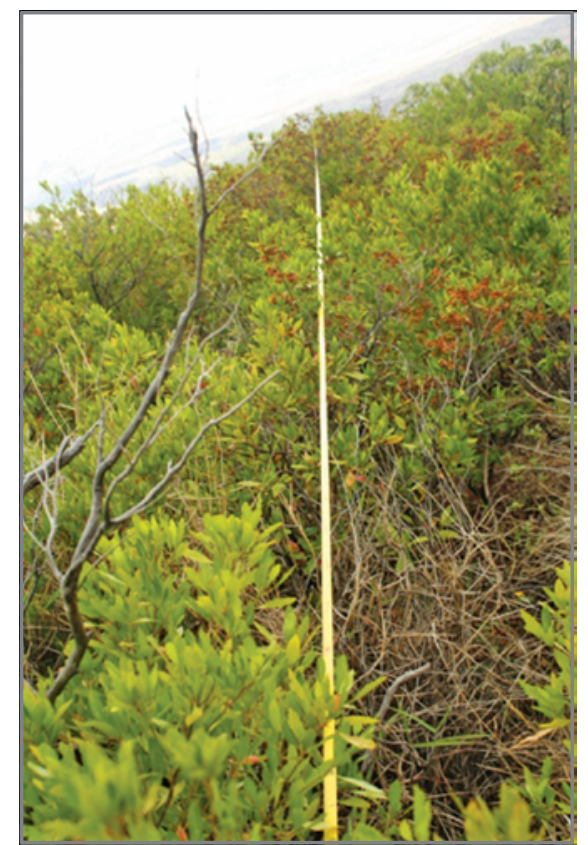

Figure 15. 'A'ali'i dry shrubland showing dense shrub canopy. The yellow band in this photo is the measuring tape used to mark field transects. (Map Unit 5)

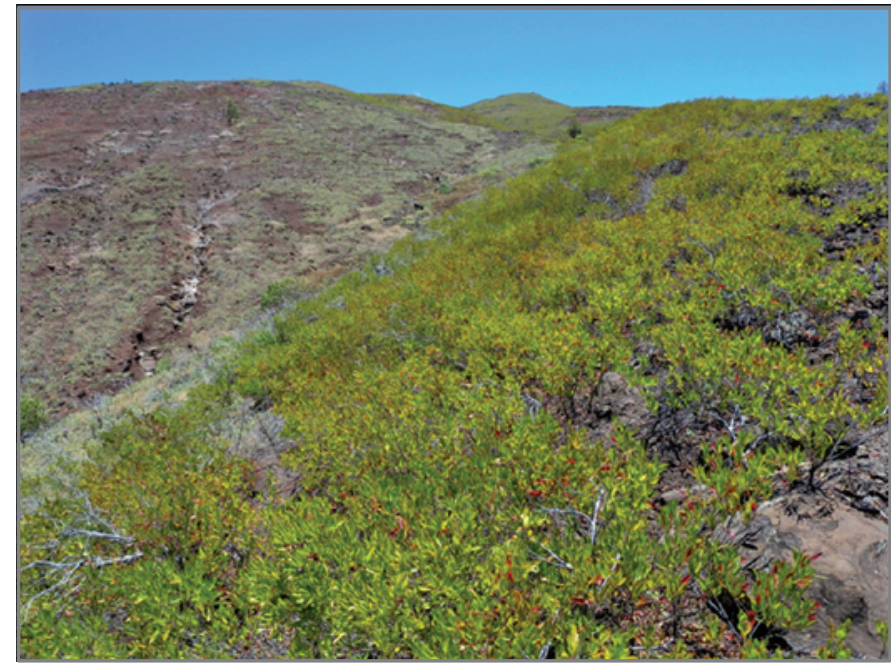

Figure 16. General view of 'a'ali'i dry shrubland in the Kawela watershed, Moloka'i. (Map Unit 5)

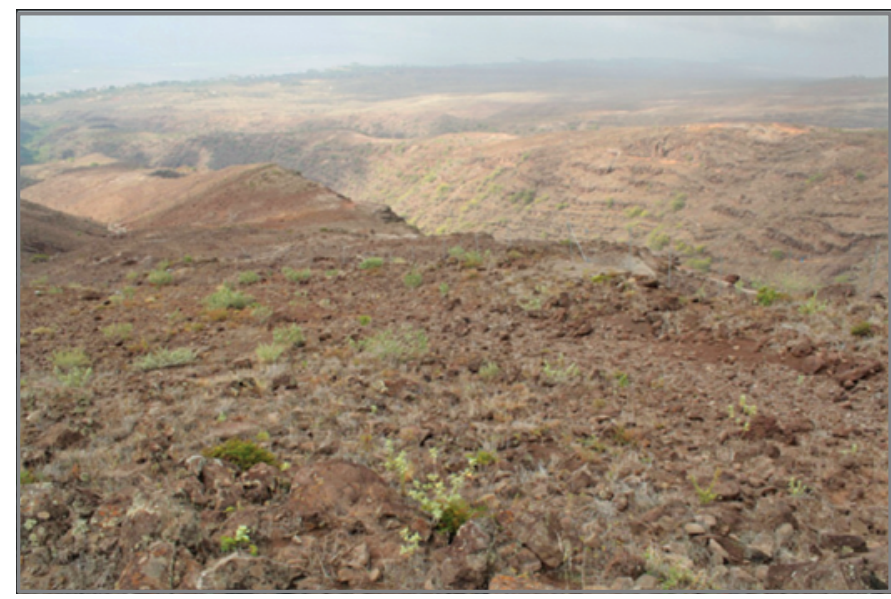

Figure 17. 'Ilima and mixed grass dry shrubland dominated by 'ilima at the edge of the east fork of Kawela Gulch, Moloka'i. (Map Unit 6) species. In areas with less 'a'ali 'i cover, other native plants can also be found, including the native shrubs 'ilima (Sida fallax), nehe (Lipochaeta rockii), kō'oko'olau (Bidens menziesii), and the native grass Panicum fauriei, as well as introduced species such as Lantana camara, Natal redtop grass (Melinis repens), molasses grass (M. minutiflora), and buffelgrass (Cenchrus ciliaris). This community currently appears to be relatively resistant to browsing by feral goats and axis deer, but is highly susceptible to fire.

\section{'Ilima and Mixed Grass Dry Shrubland (Map Unit 6)}

The 'ilima and mixed grass dry shrubland community is found on rough and rocky substrates below 1,100 m elevation in dry moisture zones and some mesic areas that receive less than $1,500 \mathrm{~mm}$ of annual rainfall (figs. 17, 18). This unit has greater than 50 percent bare ground, but a persistent cover of the native 'ilima and a few other native and alien grass, shrubs, and herbaceous plants, particularly during the wet winter months. A total of 490.9 ha of this community was mapped, which represents 9.6 percent of the project area. Although this community probably existed in a similar form prior to humans coming to the Hawaiian Islands, it would have been much more restricted in abundance and distribution at that time to a secondary successional community colonizing recent rockfall areas. Today this vegetation type is much more widespread because of the extensive browsing pressure this area has had from feral goats and axis deer, which removes most of the more palatable shrubs and grasses from the landscape, leaving only 'ilima and a few other hardy species. After a small area of this community type was fenced to exclude ungulate browsing in 2009, the vegetation changed rapidly over the next three years. By 2011 the fenced area was covered by a mixed native shrub and grass community dominated by 'ilima and 'âweoweo (Chenopodium oahuense) shrubs and the native grass Panicum fauriei (J. Jacobi, unpublished data).

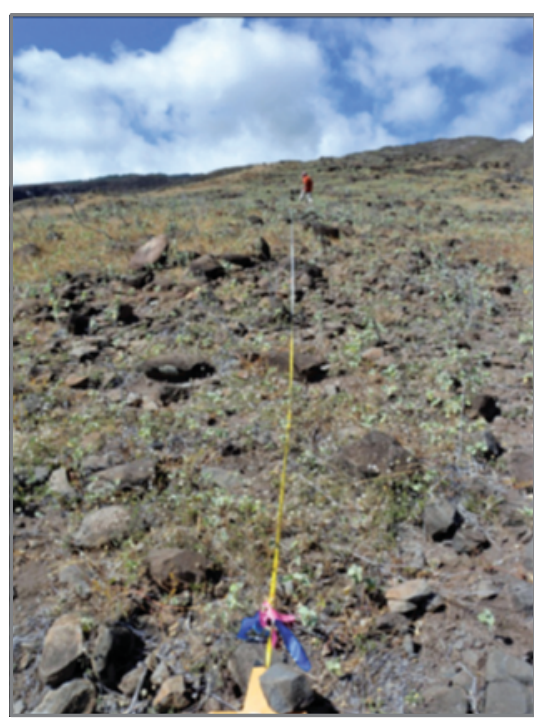

Figure 18. Very open vegetation, primarily 'ilima and Bidens pilosa shrubs with a few native and alien grasses. (Map Unit 6) 


\section{Kukui Forest (Map Unit 7)}

The Kukui forest unit is extremely simple in composition because few plants can grow in the dense shade produced by the tall trees that dominate this community (fig. 19). Kukui (Aleurites moluccana) was introduced into Hawai' $i$ by the early Polynesian settlers and has spread into many lowland mesic and wet habitats, particularly along streambeds where the trees can grow to over $30 \mathrm{~m}$ tall and form a very dense, pale green canopy. Only 3.2 ha of this community were mapped within the project area, all along the sides of streams below $800 \mathrm{~m}$ elevation. Although this unit had a very small areal distribution within the project area, it was included because its mapping signature was very distinctive and could be easily identified during the image analysis process.

\section{Mixed Alien Forest with Alien Shrub/Grass Understory (Map Unit 8)}

This plant community is really a combination of three types of units dominated by introduced tree species, ranging from the seasonal mesic zone around 1,000 m elevation nearly down to sea level in the arid zone at the coast. A total of 390.7 ha of this community was mapped, which is 7.6 percent of the project area. The upper elevation form of this community, found primarily within the seasonal mesic zone of Price and others (2012), is a mix of introduced tree species that have spread from some of the tree plantations, including Pinus spp., Eucalyptus spp., and silver oak (Grevillea robusta). The understory in this area is primarily introduced

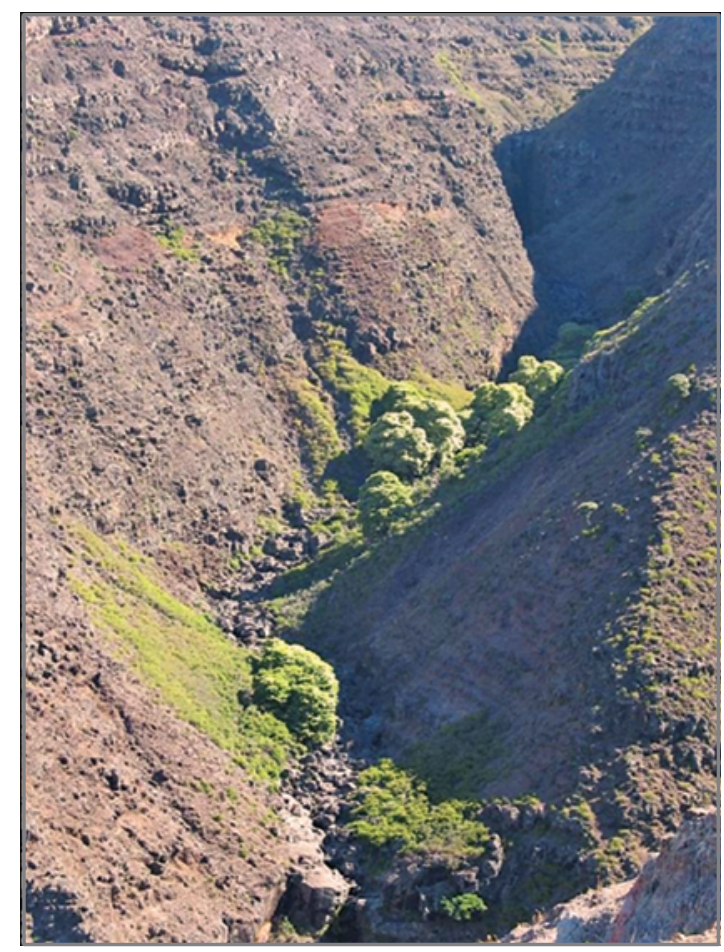

Figure 19. Stands of kukui trees in the bottom of Kawela Gulch, Moloka'i.(Map Unit 7) grass and shrub species, but in some areas the alien trees grow over remnants of the mixed mesic native shrub community. In gulch bottoms within the lower section of the mapping area, this community forms a relatively tall and dense canopy, dominated by several introduced trees including monkeypod (Samanea saman), kiawe (Prosopis pallida), and Java plum (Syzygium cumini). It has an understory composed of shrubs such as lantana (Lantana camara), koa haole (Leucaena leucocephala), and guineagrass (Urochloa maxima, also known as Panicum maximum (Clayton and Snow, 2010)) (fig. 20). The third phase of this community is open woodland dominated by Leucaena leucocephala, Java plum, and kiawe, with lantana and guineagrass forming most of the understory. The last form of this community is quite similar to the Leucaena shrubland community, but it has more tree species in its overstory (fig. 21).

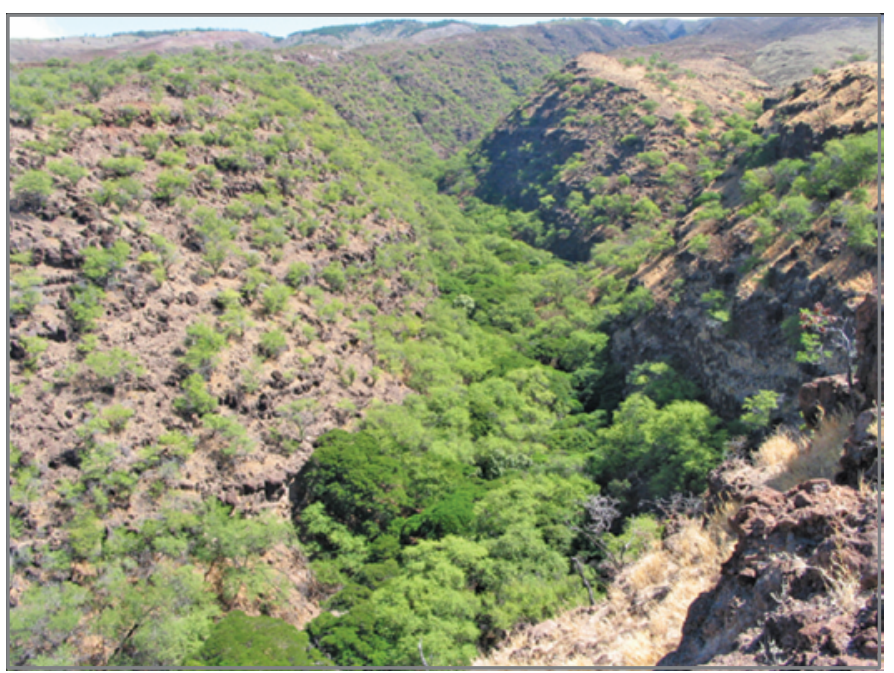

Figure 20. Tall-statured mixed alien forest in the lower section of Kawela Gulch, Moloka'i. Dominant trees in this community are kiawe, monkeypod, and java plum. (Map Unit 8)

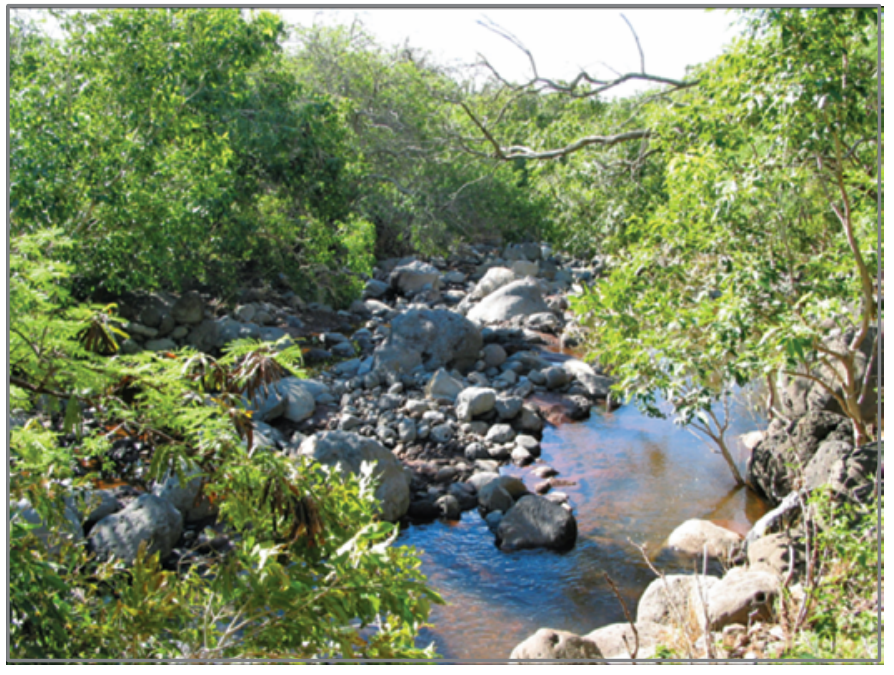

Figure 21. Low-statured mixed alien forest community in the lower part of Kamalō Gulch, Moloka'i. Dominant trees are guava (Psidium guajava), java plum, kiawe, and koa haole. (Map Unit 8) 


\section{Introduced Tree Plantation (Map Unit 9)}

There are a few tree plantations within the upper northern section of the mapped area, covering an area of 43.9 ha. These plantations mostly comprise Pinus, Eucalyptus, or Cupressaceae species that were planted more than 50 years ago (figs. 22, 23). Generally all of these stands have a tall closed canopy with trees over $20 \mathrm{~m}$ in height, resulting in a very densely shaded understory supporting few plants, including native and alien ferns and shrubs.

\section{Kiawe Woodland with Alien Grass Understory (Map Unit 10)}

The kiawe trees with alien grass understory community occupies 737.5 ha of the mapped area. This unit is found in the lower dry sections of the mapping area where annual rainfall is less than 1,200 $\mathrm{mm}$. The kiawe-dominated woodland/grassland community represents highly altered vegetation from the original plant communities that occupied this landscape in prehuman times. The degradation of this area is the result of a combination of grazing, fire, and subsequent invasion by nonnative plant species. This alien-dominated community is relatively simple in both composition and structure, dominated by an open canopy of kiawe trees up to $3 \mathrm{~m}$ tall and a dense understory composed primarily of buffelgrass (fig. 24). In places where the grass understory is more open, such as on the edges of small gullies, some additional species can be found, including the indigenous shrubs 'ilima and 'uhaloa (Waltheria indica), as well as a mix of alien grasses, herbs, and shrubs (fig. 25). This community is highly susceptible to fire and has burned many times in the past, as indicated by the abundance of charcoal in the soil and fire-scarred trees.

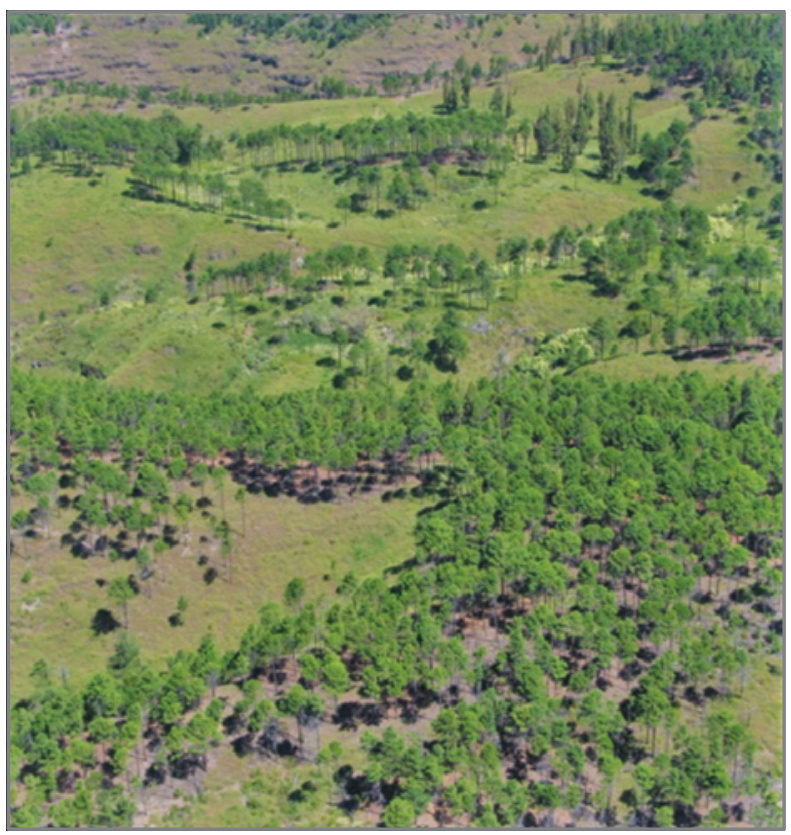

Figure 22. Aerial view of pine plantation at approximately 750 m elevation near Kawela Gulch, Moloka'i. (Map Unit 9)

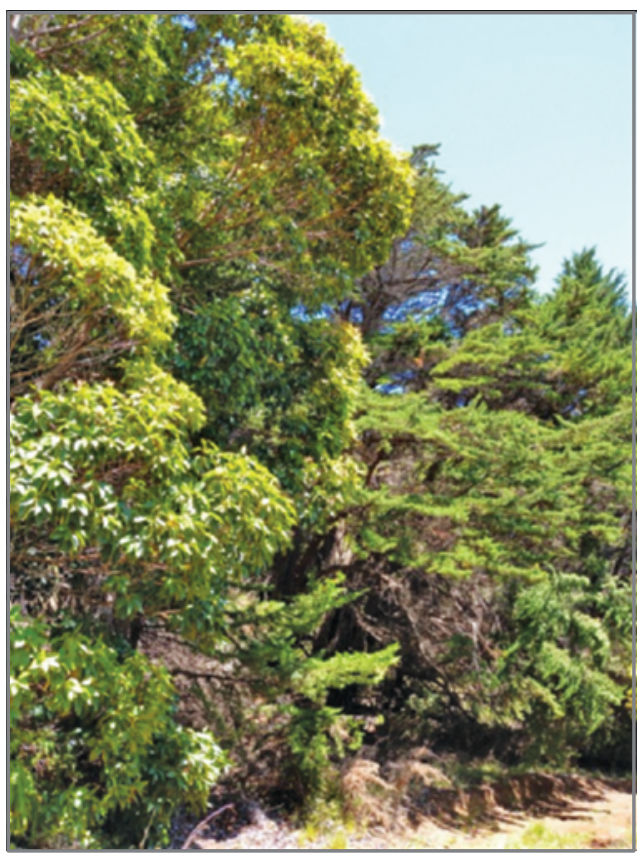

Figure 23.

Introduced tree plantation near Pu'u Kolekole, Moloka'i, dominated by Cupressaceae, Eucalyptus, and other broadleaf species. (Map Unit 9)

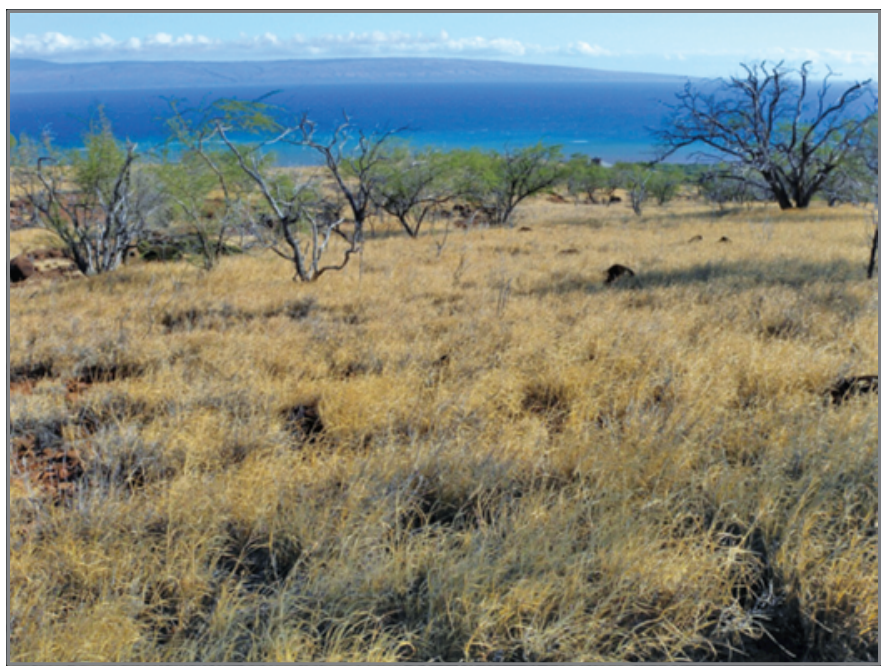

Figure 24. Kiawe trees growing in grassland dominated by the alien buffelgrass. (Map Unit 10)

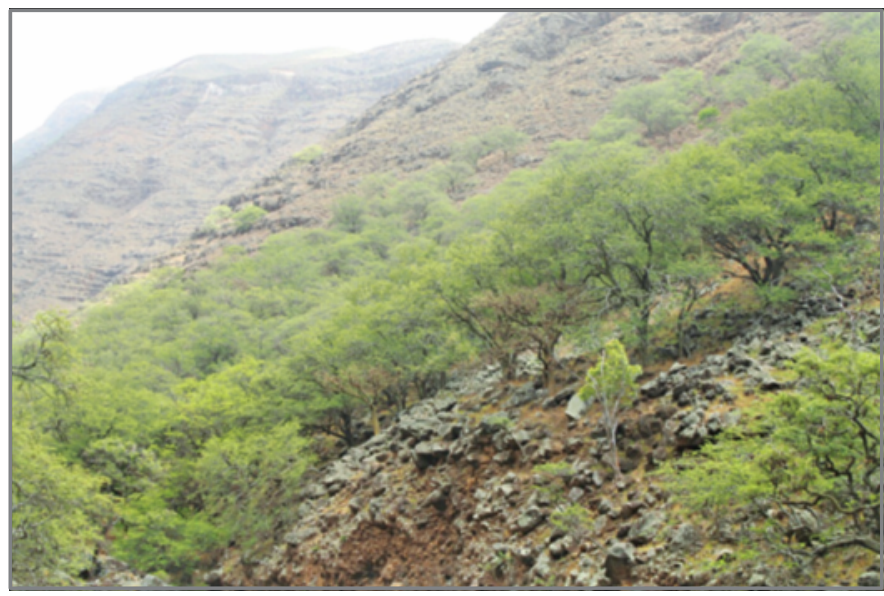

Figure 25. Kiawe woodland with alien grass understory community on the edge of Kawela Gulch, Moloka'i. (Map Unit 10) 


\section{Lantana Shrubland (Map Unit 11)}

The Lantana shrubland community was found in very small patches but was widely distributed-from near sea level at the coast to approximately $800 \mathrm{~m}$ elevation, but covering only a total of 10.7 ha within the project area. This map unit had a distinct signature that could be identified consistently because it is predominately monospecific — dominated by just one species, Lantana camara (fig. 26). It was mostly found in the moderately dry, very dry, and arid moisture zones, but a few lantana plants were found in disturbed sites within the seasonal mesic habitat. The shrubs grow to $1 \mathrm{~m}$ tall, and they can form dense patches that are quite difficult to walk through, particularly because the stems have short thorns.

\section{Koa Haole Shrubland (Map Unit 12)}

The koa haole shrubland community was the most difficult one to map because the dominant species, koa haole, is summer-deciduous and is hard to detect when it loses its leaves. This species can also be heavily browsed by feral ungulates, further masking its visibility on an image. Most of the koa haole shrubland community was found in the eastern section of the project area, particularly on the lower sections of Kamalō Gulch. Overall, 168.6 ha of this community were mapped in the dry and very dry moisture zones below $700 \mathrm{~m}$ elevation. Koa haole may grow like a small tree up to $3 \mathrm{~m}$ tall, but it is more often found in this area as shrub less than $2 \mathrm{~m}$ in height (figs. 27, 28). The canopy of this unit is relatively open and the understory is generally occupied by a mix of alien shrubs and alien grasses (buffelgrass, guinea grass, molasses grass), as well as the ubiquitous native shrub 'ilima.

\section{Mixed Alien Grass with 'llima Shrubs (Map Unit 13)}

A total of 392.3 ha of this alien grassland community was mapped throughout most of the project area-from near sea level at the coast to approximately $1,100 \mathrm{~m}$ elevation at the edge of the closed forest (fig. 29). A few small grassdominated patches were also mapped in disturbed openings within the closed mesic 'ōhi 'a forest unit. In the lower dry section of the area, this community is heavily dominated by a number of introduced grass species, including buffelgrass (fig. 30), although other species such as Natal redtop grass, sandbur (Cenchrus echinatus), and thatching grass (Hyparrhenia rufa) are also found within the grassland. The native shrub 'ilima is widely distributed throughout this community but does not attain significant cover. Many other alien shrubs and herbaceous species are also found here, as well as the indigenous herb "uhaloa, but again in low cover. Along the coast, this map unit included some dense stands of the alien herb Batis maritima (pickleweed) in wetland habitat. The spectral signature of Batiswas very similar to the other alien grass species, so they were combined into a single

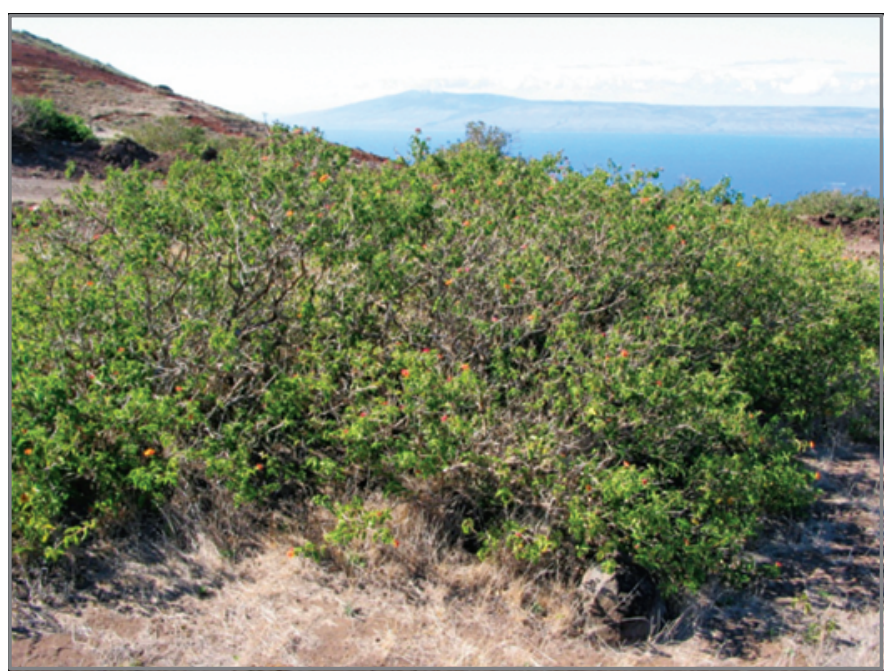

Figure 26. Lantana shrubland. (Map Unit 11)

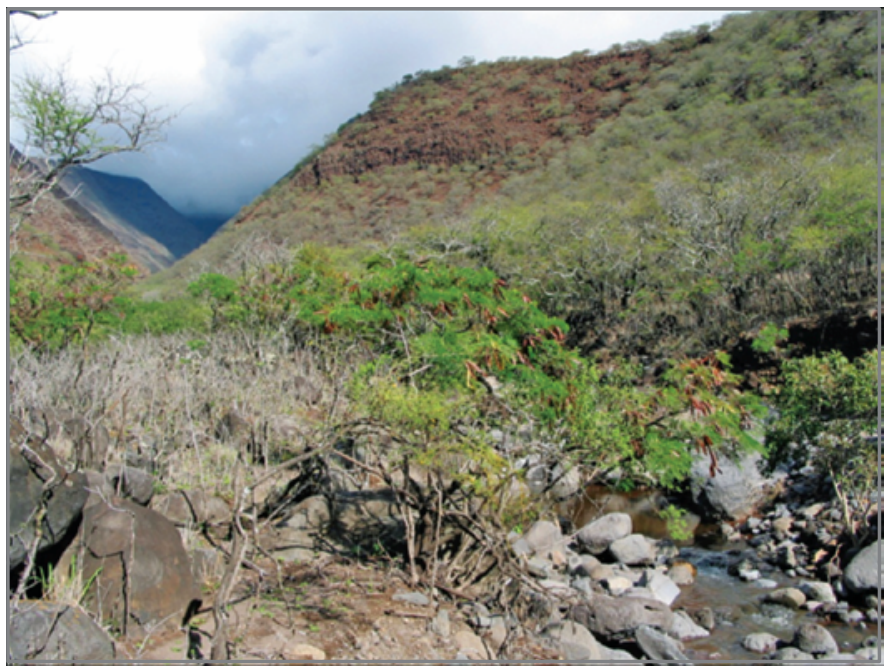

Figure 27. Koa haole shrubland in lower part of Kamalō Gulch, Moloka'i. (Map Unit 12)

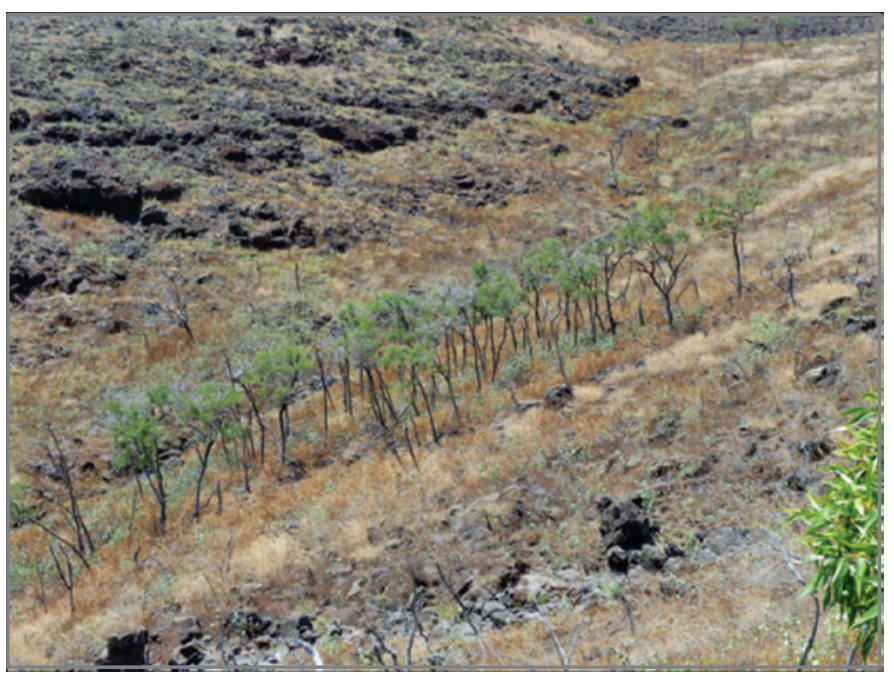

Figure 28. Small stand of koa haole growing above alien grasses in the lower part of the Kawela watershed, Moloka'i. (Map Unit 12) 


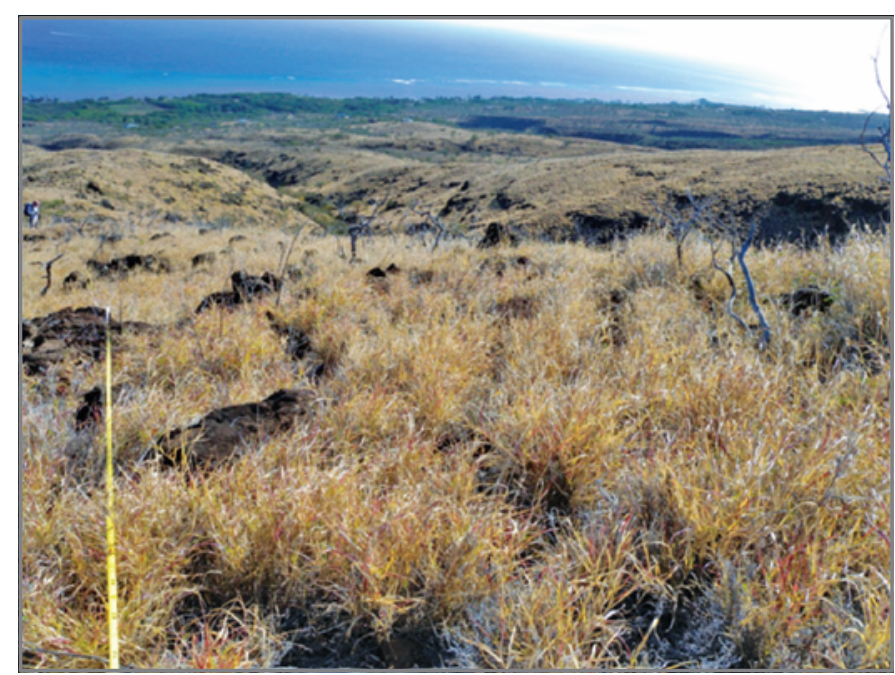

Figure 29. Mixed alien grassland dominated by buffelgrass. The yellow band in this photo is the measuring tape used to mark field transects. (Map Unit 13)

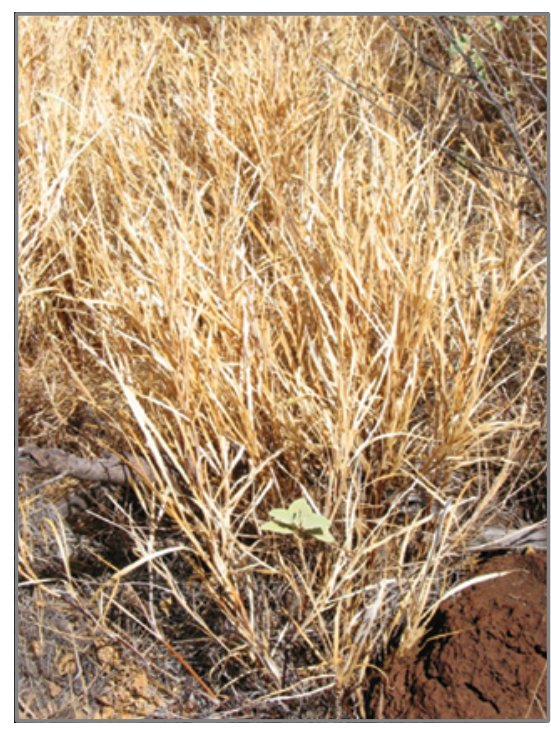

Figure 30. Close-up of buffelgrass and seedling of 'ilima. (Map Unit 13)

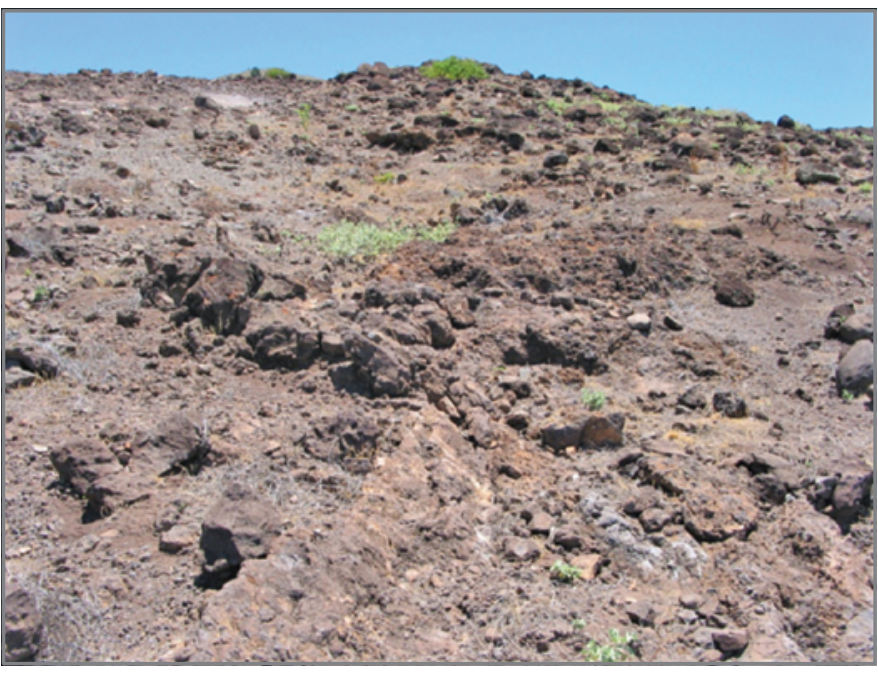

Figure 31. Not vegetated or very sparse grass/shrub community at the edge of the upper east fork of Kawela Gulch, Moloka'i. (Map Unit 14) map unit. At higher elevations (above 1,000 m elevation), the dominant grass species in this unit was molasses grass, which forms very dense monospecific patches of grassland.

\section{No Vegetation or Very Sparse Grasses I Shrubs (Map Unit 14)}

The not vegetated map unit is very similar to the "ilima and mixed grass dry shrubland, but it has even less plant cover (figs. 31, 32). This very sparse plant community was found extensively across the project area, covering a total of 836.4 ha, ranging from approximately $1,100 \mathrm{~m}$ elevation to near sea level at the coast. This unit was found on two different types of substrates: very rocky areas, such as steep sides of gulches or on ridges that have been heavily eroded, and bare areas that still have fine substrate. These latter nonvegetated sites can be a major source of sediment as surface flow following heavy rainfall runs through those sites. The few plants that are found in this unit include small individuals of 'ilima, Spanish needle (Bidens pilosa), Dysphania carinatum (formerly called Chenopodium carinatum), as well as native and alien grasses such as Panicum fauriei, buffelgrass, and Natal redtop grass.

\section{Map Accuracy Assessment}

We tested the accuracy of the vegetation map by comparing mapped community units with the vegetation interpreted from high-resolution georectified aerial imagery obtained from Pictometry OnLine (POL) at a set of 100 points randomly located across the mapping area (tables 4-6). However, most of the mapped units that are relatively small in spatial extent received only a small number of accuracy assessment points - resulting in lower confidence of their

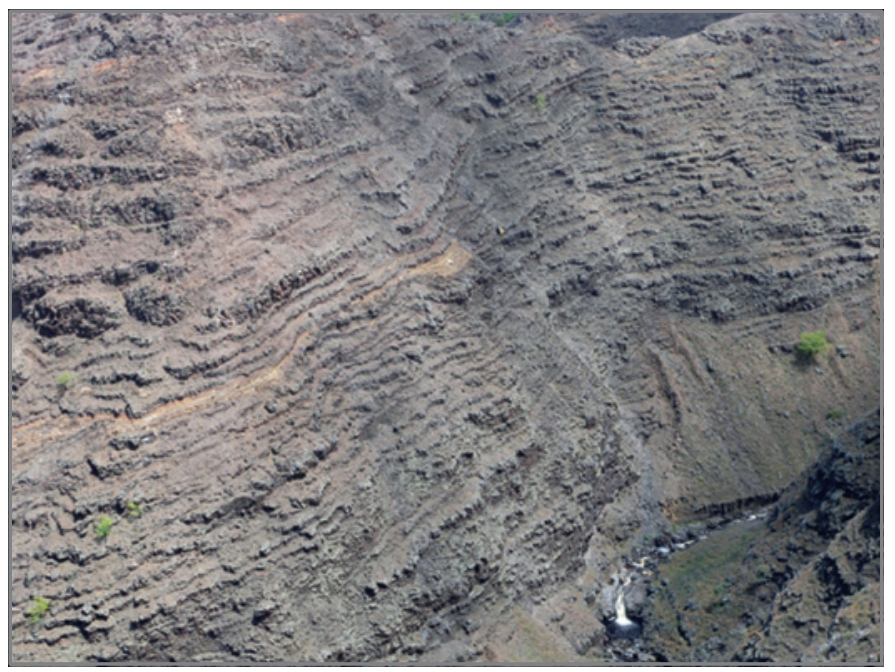

Figure 32. Steep slopes of the upper east fork of Kawela Gulch, Moloka'i. These steep cliff faces have very little vegetation, primarily alien grass and shrub species, plus the native shrub 'ilima. (Map Unit 14) 
Table 4. Error matrix for the accuracy assessment conducted at 100 randomly located sample plots across the Kawela-Kamalō Ridgeto-Reef project area, depicting agreement or disagreement between the dominant class mapped in an assessment plot to the first-choice classification unit from the Pictometry Online imagery service $(\mathrm{POL})$ image assessment.

[Grey boxes indicate number of ground reference plots that agree with the vegetation map]

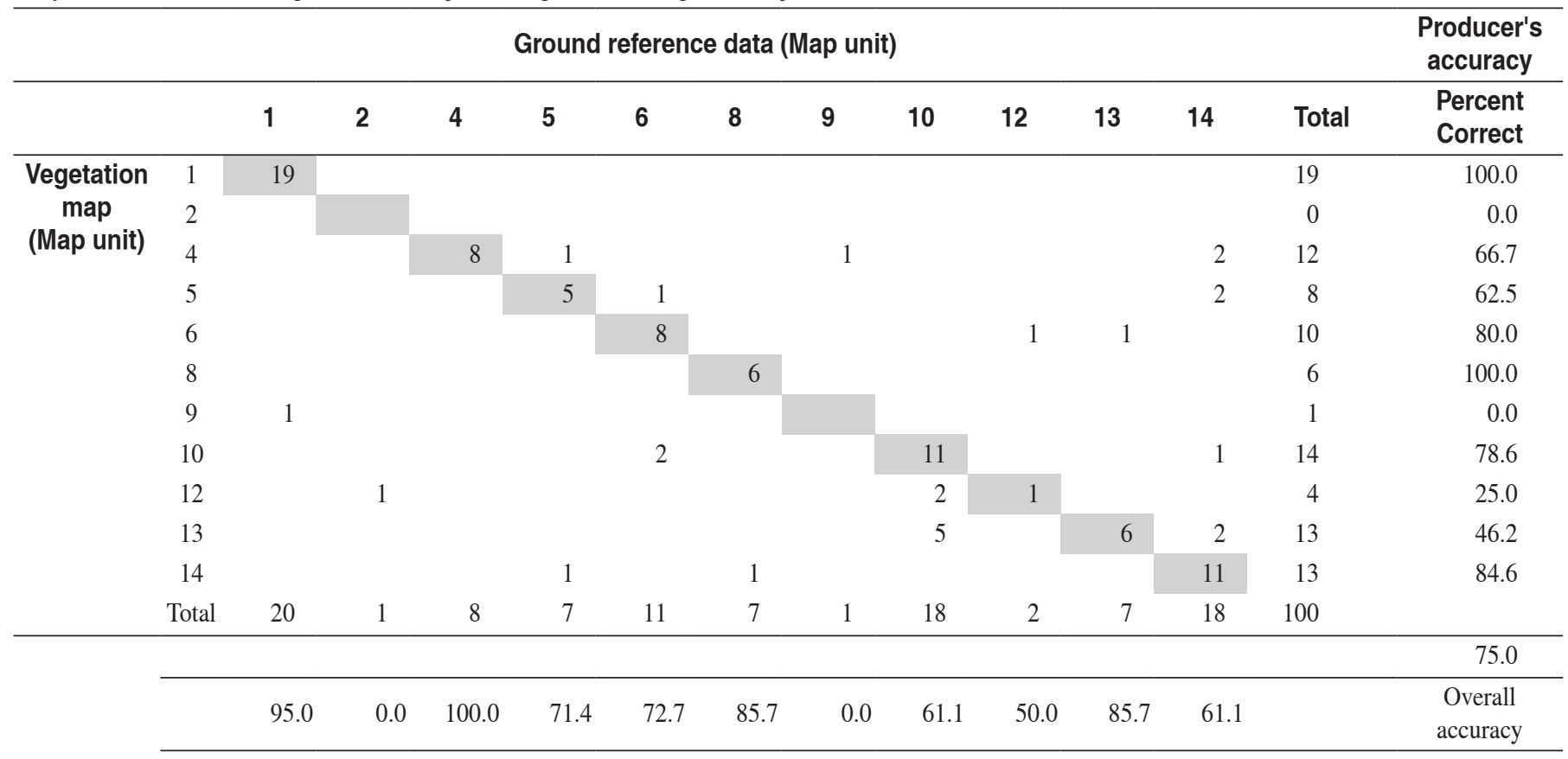

Table 5. Error matrix for the accuracy assessment conducted at 100 randomly located sample plots across the Kawela-Kamalō Ridgeto-Reef project area, depicting agreement or disagreement between the two most abundant classes mapped within an assessment plot to either the first- or second-choice classification unit from the Pictometry Online imagery service (POL) image assessment.

[Grey boxes indicate number of ground reference plots that agree with the vegetation map]

\begin{tabular}{|c|c|c|c|c|c|c|c|c|c|c|c|c|c|c|c|}
\hline \multicolumn{15}{|c|}{ Ground reference data (Map unit) } & \multirow{2}{*}{$\begin{array}{c}\begin{array}{c}\text { Producer's } \\
\text { accuracy }\end{array} \\
\text { Percent } \\
\text { Correct }\end{array}$} \\
\hline & & 1 & 2 & 4 & 5 & 6 & 8 & 9 & 10 & 12 & 13 & 14 & & Total & \\
\hline \multirow{15}{*}{$\begin{array}{c}\text { Vegetation } \\
\text { map } \\
\text { (Map unit) }\end{array}$} & 1 & 20 & & & & & & & & & & & & 20 & 100.0 \\
\hline & 2 & & & & & & & & & & & & & 0 & 0.0 \\
\hline & 4 & & & 8 & 1 & & & & & & & 1 & & 10 & 80.0 \\
\hline & 5 & & & & 5 & 1 & & & & & & 1 & & 7 & 71.4 \\
\hline & 6 & & & & & 12 & & & & 1 & & & & 13 & 92.3 \\
\hline & 8 & & & & & & 6 & & & & & & & 6 & 100.0 \\
\hline & 9 & & & & & & & 1 & & & & & & 1 & 100.0 \\
\hline & 10 & & & & & & & & 16 & & & 1 & & 17 & 94.1 \\
\hline & 12 & & 1 & & & & & & 1 & 1 & & & & 3 & 33.3 \\
\hline & 13 & & & & & & & & 1 & & 6 & & & 7 & 85.7 \\
\hline & 14 & & & & & & 1 & & & & & 14 & & 15 & 93.3 \\
\hline & 15 & & & & 1 & & & & & & & & & 1 & 0.0 \\
\hline & Total & 20 & 1 & 8 & 7 & 13 & 7 & 1 & 18 & 2 & 6 & 17 & 0 & 100 & \\
\hline & & & & & & & & & & & & & & & 89.0 \\
\hline & & 100.0 & 0.0 & 100.0 & 71.4 & 92.3 & 85.7 & 100.0 & 88.9 & 50.0 & 100.0 & 82.4 & 0.0 & & $\begin{array}{c}\text { Overall } \\
\text { accuracy }\end{array}$ \\
\hline
\end{tabular}


Table 6. Error matrix for the accuracy assessment conducted at 100 randomly located sample plots across the Kawela-Kamalō Ridgeto-Reef project area, depicting agreement or disagreement between any of the classes mapped within an assessment plot to any of the classification units identified within that plot during the Pictometry Online imagery service (POL) image assessment.

[Grey boxes indicate number of ground reference plots that agree with the vegetation map]

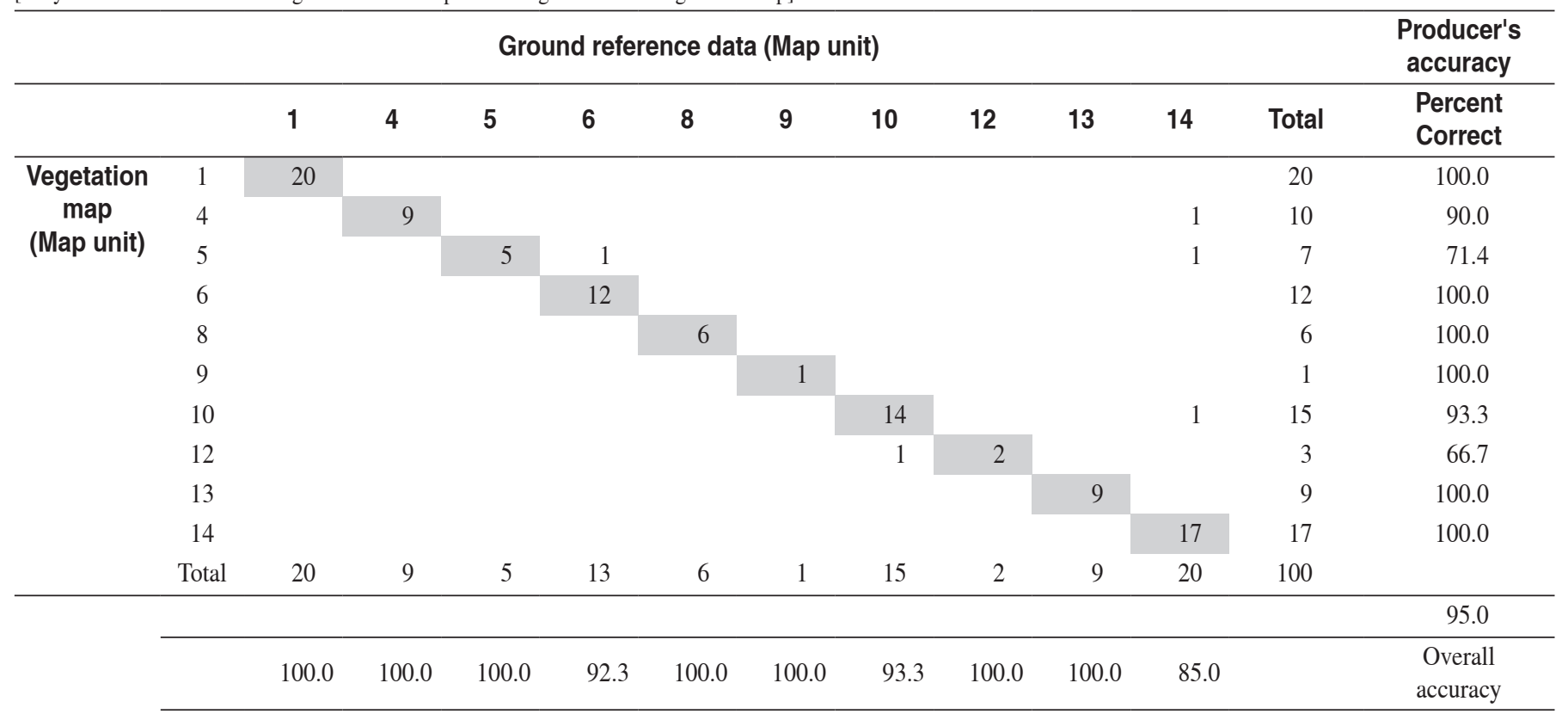

calculated accuracy values. The accuracy assessment analysis yielded three levels of overall accuracy: 75.0, 89.0, and 95.0 percent, depending on how the map data and the reference plot data were compared. The lowest accuracy was obtained when just the dominant class mapped in an assessment plot was compared to the first-choice classification unit from the POL image assessment. The greatest accuracy value came from a comparison among any of the classes mapped within an assessment plot to any of the classification units identified within that plot during the POL image assessment. Given the high spatial resolution (and corresponding small pixel size) of the QuickBird imagery used to create the map, it seems reasonable to be more robust with the analysis, particularly since an observer in the field would have a difficult time accurately locating a point with less than a 1-m error without differential correction of the GPS coordinates. The horizontal positional error from the original QuickBird image used for mapping was determined to be between 5 and $8 \mathrm{~m}$, which could also account for some of the difference in location between the mapping and assessment images. Additionally, many of the mapped units are closely related to each other. For example, Map Unit 6 ('ilima and mixed grass dry shrubland), Map Unit 13 (mixed alien grass with 'ilima shrubs), Map Unit 12 (koa haole shrubland), and Map Unit 14 (no vegetation or very sparse grasses / shrubs) share many species and differ primarily on the cover of one or two of the dominant plant species or the amount of nonvegetated ground within the unit. The error matrix for the most restrictive assessment (table 4) indicates low user's accuracy values (that is, less than 75 percent) for many of these units. There are fewer lower accuracy values in table 5 , where a comparison is made between the two most abundant plant communities within the assessment plot on the map versus the first two map units identified from the POL image assessment. In the most robust comparison between the data for the plots on the map and the POL data (table 6), only Map Units 5 ('a'ali 'i dry shrubland) and 12 (koa haole shrubland) had a producer's accuracy value less than 75 percent.

Some of the inaccuracy found in the map may be due to seasonal or temporal changes in the vegetation between the time when the QuickBird image used for mapping was taken (August 2004) and the date of the POL imagery (20092010). Unfortunately, we were not able to collect the "field" assessment dataset until the POL imagery became available. However, we feel that the user of the resulting map will be able to get a reasonable perspective of our mapping accuracy from this analysis.

\section{Discussion}

The preponderance of mapping units that are dominated by alien plant species is a strong indication of how much disturbance has occurred in nearly half of the project area. The major factors causing such a dramatic change include logging of 'iliahi (sandalwood) trees in the 19th century (Cuddihy and Stone, 1990); grazing by domestic cattle, feral goats and pigs, and introduced axis deer; numerous fires; and invasion and competition from nonnative plant species. The current vegetation in the approximately 50 percent of the project area 
that was mapped with units dominated by alien species is dramatically different in composition, and probably also structure, from the original plant communities that would have been found there. The vegetation zones described by Price and others (2012) (fig. 3) indicate the lower half of the project area was covered by lowland dry forest that was likely dominated by a diverse mixture of native tree, shrub, grass, and herbaceous species.

The native-dominated 'ōhi'a forest and uluhe fern communities in the upper portion of the project area are probably most similar to the vegetation that was originally found in this area and correspond very closely to the distribution of montane wet and mesic forest in the Price and others (2012) vegetation zone map (fig. 3). Portions of the mixed mesic native shrub community still persist in the area mapped by Price and others as the lowland mesic zone. However, below that area the vegetation is either dominated by alien species, or artificially opened by animal grazing and erosion. Both the ' $a$ 'ali' $i$ dry shrubland and open 'ilima mixed grass dry shrubland vegetation units are likely seral communities that persist as secondary succession units that have responded positively to the disturbance to the original vegetation. Jonathan Price (University of Hawai' ${ }^{i}$ at Hilo, oral commun., 2011) speculates that the lowland mesic zone was likely covered by a diverse mixed mesic forest, remnants of which are still found in the upper elevation mesic gulches. Below this area in the lowland dry zone, he suggests that the vegetation was a mixed tree/shrub/grass savannah, with several dry forest tree species in the open overstory and native shrubs and grasses filling in the understory. Steeper slopes in the gulches would likely have been dominated by either native shrub or grass species, depending upon how long the vegetation had to become established following rock slides, and very little bare ground was originally exposed, except in the steepest areas or in the open stream beds.

\section{Conclusions}

The map produced for the Kawela to Kamalō watersheds can be used as a baseline for assessing the distribution and abundance of the various plant communities found across this landscape at the time of the imagery (2004). It can also serve as a backdrop for studying the dynamics of the vegetation and other attributes of this watershed, such as erosion and surface transport of sediment, relative to current and future habitat conditions. The future composition and structure of the vegetation of this entire area will be determined by the levels of management applied to the various factors that influence the habitats found within the project area. If ungulate browsing and grazing pressure can be reduced or eliminated, and wildfires are prevented, it is likely that some of the areas that are now mostly bare may become revegetated, even by native species of plants, potentially reducing erosion throughout this area.

\section{References}

Blaschke, T., 2010, Object based image analysis for remote sensing: ISPRS Journal of Photogrammetry and Remote Sensing, v. 65, p. $2-16$.

Brown de Colstoun, E.C., Story, M.H., Thompson, C., Commisso, K., Smith, T.G., and Irons, J. R., 2003, National Park vegetation mapping using multitemporal Landsat 7 data and a decision tree classifier: Remote Sensing of Environment, v. 85, p. 316-327.

Clayton, W.D., and Snow, Neil, 2010, A key to Pacific grasses: Kew Publishing, Royal Botanic Gardens, Kew (London).

Cogan, D., Schulz, K., Benitez, D., Kudray, G., and Ainsworth, A., 2011, Vegetation inventory project; Pu 'ukoholā Heiau National Historic Site: Natural Resource Report NPS/PUHE/ NRR-2011/459, National Park Service, Fort Collins, Colo. (Also available at https://irma.nps.gov/App/Reference/Profile/2176695.)

Congalton, R.G., 1991, A review of assessing the accuracy of classifications of remotely sensed data: Remote Sensing of Environment, v. 37, p. 35-46.

Cuddihy, L.W., and Stone, C.P., 1990, Alteration of native Hawaiian vegetation-Effects of humans, their activities and introductions: Honolulu, University of Hawaii Press.

Federal Geographic Data Committee. 2008, National Vegetation Classification Standard, Version 2 FGDC-STD-005-2008: Vegetation Subcommittee, Federal Geographic Data Committee, FGDC Secretariat, U.S. Geological Survey, Reston, Va. (Also available at http://usnvc.org/wp-content/uploads/2011/02/NVCS_ V2_FINAL_2008-02.pdf.)

Giambelluca, T.W., Chen, Q., Frazier, A.G., Price, J.P., Chen, Y.L., Chu, P.S., Eischeid, J., and Delparte,D., 2011, The rainfall atlas of Hawai 'i: Honolulu, University of Hawai' at Manoa. (Also available at http://rainfall.geography.hawaii.edu.)

Gon, S.M., III, 2006, The Hawai 'i Gap Analysis Project final report: Honolulu, University of Hawai'i, Research Corporation of the University of Hawai'i, 163 p.

Grossman, D.H., Faber-Langendoen, D., Weakley, A.S., Anderson, M., Bourgeron, P., Crawford, R., Goodin, K., Landaal, S., Metzler, K., Patterson, K.D., Pyne, M. Reid, M., and Sneddon, L., 1998. International classification of ecological communities-Terrestrial vegetation of the United States. Volume I. The National Vegetation Classification System; development, status, and applications: Arlington, Va., The Nature Conservancy. (Also available at http:// www.natureserve.org/library/vol1.pdf.)

Jacobi, J.D., 1990. Distribution maps, ecological relationships, and status of native plant communities on the island of Hawai ' $\mathrm{i}$ : Honolulu, University of Hawaii at Manoa, Ph.D. dissertation, 290 p., 2 pls., 31 figs.

Kirch, P.V., 1998, Archaeology, in Juvik, S.P., Juvik, J.O., and Paradise, T.R., eds., Atlas of Hawaii: Honolulu, University of Hawaii Press, p. 161-168. 
Kirch, P.V., 2007, Three islands and an archipelago; reciprocal interactions between humans and island ecosystems in Polynesia: Earth and Environmental Science Transactions of the Royal Society of Edinburgh, v. 98, p. 85-99.

Kirch, P.V., and Hunt, T L., 1997, Historical ecology in the Pacific Islands: New Haven, Conn., Yale University Press.

Krajina, V.J., 1963, Biogeoclimatic zones on the Hawaiian Islands: Hawaiian Botanical Society Newsletter, v. 2, p. 93-98.

Mueller-Dombois, D., 1966, The vegetation map and vegetation profiles, chap. 8 of Doty, M.S., and Mueller-Dombois, D., eds., Atlas and bioecology studies in Hawaii Volcanoes National Park: Honolulu, University of Hawaii Press, 472 p.

Mueller-Dombois, D., 1984, Classification and mapping of plant communities-A review with emphasis on tropical vegetation, in Woodell, G.M., ed., The role of terrestrial vegetation in the global carbon cycle; measurement by remote sensing: New York, John Wiley \& Sons Inc,, p. 21-88.

Mueller-Dombois, D., and Ellenberg, H., 1974, Aims and methods of vegetation ecology: New York, London, Sydney, Toronto, John Wiley \& Sons Inc.

NatureServe, 2010, International ecological classification standardTerrestrial ecological classifications; descriptions of ecological systems for modeling of LANDFIRE biophysical settings, State of Hawai 'i: Arlington, Va., NatureServe, Report.

NatureServe, 2011, Terrestrial ecological classifications-ecological systems of Hawai' 'i: Arlington, Va, and Boulder, Colo., NatureServe, Technical Report.

Pratt, L.W., and Gon, S.M., III, 1998, Terrestrial ecosystems, in Juvik, S.P., Juvik, J.O., and Paradise, T.R., eds., Atlas of Hawaii: Honolulu, University of Hawaii Press, p. 121-129.

Pratt, L.W., and Jacobi, J.D., 2009, Loss, degradation, and persistence of habitats, in Pratt, T.K., Atkinson, C.T., Banko, P.C., Jacobi, J.D., and Woodworth, B.L., eds., Conservation biology of Hawaiian forest birds, implications for Island avifauna: New Haven, Conn., and London, Yale University Press, p, 139-158.

Price, J.P., Jacobi, J.D., Gon, S.M., III, Matsuwaki, D., Mehrhoff, L., Wagner, W.L., Lucas, M., and Rowe, B., 2012, Mapping plant species ranges in the Hawaiian Islands-Developing a methodology and associated GIS layers: U.S. Geological Survey Open-File Report 2012-1192, 38 p. (Also available at: http://pubs. usgs.gov/of/2012/1192/of2012-1192_text.pdf)

Ripperton, J.C., and Hosaka, E.Y., 1942, Vegetation zones of Hawaii: Hawaii Agricultural Experiment Station Bulletin 89, p. 1-60.

Robyns, W., and Lamb, S.H., 1939, Preliminary ecological survey of the island of Hawaii: Bulletin du Jardin Botanique de L'e'tat, Bruxelles, v. 15, p. 241-293.

Shaw, R.B., and Castillo, J.M., 1997, Plant communities of Pohakuloa Training Area: Ft. Collins, Colo., Colorado State University, Center for Ecological Management of Military Lands, Department of Forest Sciences.
Sherrod, D.R., Sinton, J.M., Watkins, S.E., and Brunt, K.M., 2007, Geologic map of the State of Hawai 'i: U.S. Geological Survey Open-File Report 2007-1089, scale 1:100,000 and 1:250,000. (Also available at http://pubs.usgs.gov/of/2007/1089/.)

Shimwell, D.W., 1971, The description and classification of vegetation: Seattle, Wash., University of Washington Press.

Smith, C.W., 1985, Impact of alien plants on Hawaii's native biota, in Stone, C.P., and Scott, J.M., eds., Hawaii's terrestrial ecosystems; preservation and management: Honolulu, University of Hawaii, Department of Botany, Cooperative National Park Resources Studies Unit, p. 180-250.

Staples, G.W., and Cowie, R.H., eds., 2001, Hawaii's invasive species; a guide to invasive plants and animals in the Hawaiian Islands (1st ed.): Honolulu, Mutual Publishing and the Bishop Museum Press.

Stehman, S.V., and Czaplewski, R.L., 1998, Design and analysis for thematic map accuracy assessment; fundamental principles: Remote Sensing of Environment, v. 64, p. 331-344.

Stock, J.D., Cochran, S.A., Field, M.E., Jacobi, J.D., and Tribble, G., 2011, From ridge to reef-linking erosion and changing watersheds to impacts on the coral reef ecosystems of Hawai ' $i$ and the Pacific Ocean: U.S/. Geological Survey Fact Sheet 2011-3049. (Also available at http://pubs.usgs.gov/fs/2011/3049/.)

Stone, C.P., and Scott, J.M., eds., 1985, Hawaii's terrestrial ecosystems; preservation and management: Proceedings of a Symposium Held June 5-6, 1984, at Hawaii Volcanoes National Park: Honolulu, University of Hawaii, Department of Botany, Cooperative National Park Resources Studies Unit.

U.S. Geological Survey, 2009, LANDFIRE.HI_100EVC: Hawai ${ }^{i} i$ existing vegetation type layer: U.S. Geological Survey. (Also available at http://landfire.cr.usgs.gov/viewer/viewer.html?b box $=-164,15.79,-151.67,25.48$.)

Wagner, W L., Herbst, D.R., and Lorence, D.H., 2012, Flora of the Hawaiian islands: Washington, D.C., Smithsonian Institution, Department of Botany. (Also available at http://botany.si.edu/ pacificislandbiodiversity/hawaiianflora/index.htm.)

Wagner, W.L., Herbst, D.R., and Sohmer, S.H., 1999, Maunal of the flowering plants of Hawaii (2d ed.): Honolulu, University of Hawaii Press, Bishop Museum Press.

Wang, Y., ed.. 2012, Remote sensing of protected lands: Terre Haute, Ind., CRC Press.

Warshauer, F.R., 1998, Alien species and threats to native ecology, in Juvik, S.P., Juvik, J.O., and Paradise, T.R., eds., Atlas of Hawaii: Honolulu, University of Hawaii Press, p, 146-149.

Xie, Y., Sha, Z., and Yu, M., 2008, Remote sensing imagery in vegetation mapping —a review: Journal of Plant Ecology v. 1, p. 9-23. 


\section{Appendix 1}




\section{Appendix 1. Species Distribution}

Appendix 1 Table. Occurrence of species in the various map units.

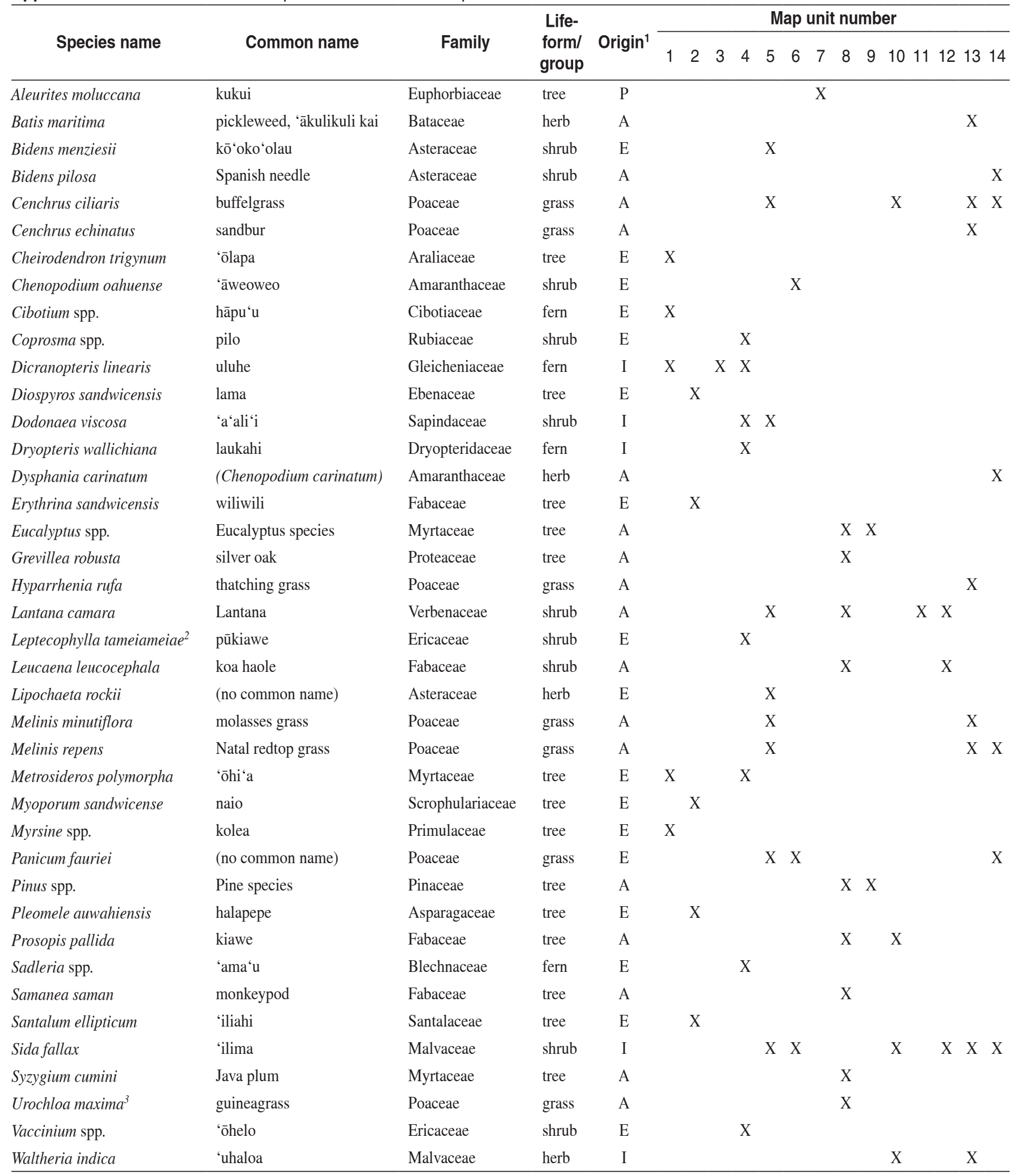

${ }^{1}$ Origin: A, introduced alien species; E, endemic species; I, indigenous species; P, Polynesian introduction.

${ }^{2}$ This species was formerly known as Styphelia tameiameiae

${ }^{3}$ This species was formerly known as Panicum maximum 
Menlo Park Publishing Service Center, California Manuscript approved for publication, April 18, 2013 Edited by Larry Slack and Peter H. Stauffer Design and layout by Jeanne S. DiLeo 


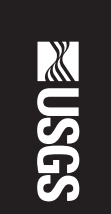

๙్ర్

ฆ

으

홍

क

क्ष

음

종

을

蛋

审

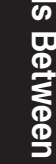

蛋

$\frac{\Phi}{10}$

言

즐

임

옹

क्ष

옥

음

응

졸

J

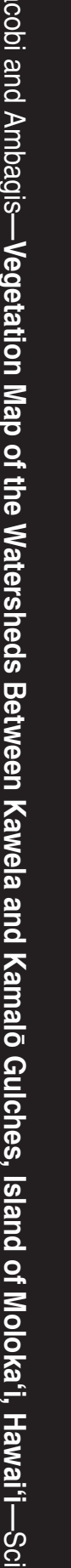

Ф.

言

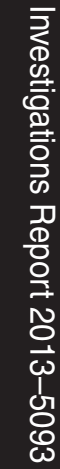

